\title{
35. MAJOR- AND TRACE-ELEMENT VARIATIONS IN BASALTS FROM THE NORTH PHILIPPINE SEA DRILLED DURING DEEP SEA DRILLING PROJECT LEG 58: A COMPARATIVE STUDY OF BACK-ARC-BASIN BASALTS WITH LAVA SERIES FROM JAPAN AND MID-OCEAN RIDGES
}

\author{
D. A. Wood, ${ }^{1}$ J.-L. Joron, ${ }^{2}$ N. G. Marsh, ${ }^{1}$ J. Tarney, ${ }^{1}$ and M. Treuil ${ }^{2}$
}

\begin{abstract}
Major- and trace-element data for 51 samples from the basalt cores recovered during Deep Sea Drilling Project Leg 58 from the north Philippine Sea are used to establish compositional variations in oceanic crust formed in a back-arc-basin tectonic environment. The basalts from the Shikoku Basin are predominantly aphyric, tholeiitic basalts with $\mathrm{Mg}$-numbers between 0.6 and 0.7 and similar in traceelement chemistry to normal mid-ocean-ridge basalt (MORB). However, an Fe-poor, alkali-basalt sill forms part of the crustal section at Site 444. Also, some of the tholeiitic units from each of the Shikoku Basin sites are enriched in the hygromagmatophile (incompatible) trace elements relative to normal MORB and are similar in composition to basalts erupted in Iceland and along the Reykjanes Ridge. Basalts forming a sequence of sills in the one site drilled in the Daito Basin include both alkalic and tholeiitic types. These basalts have low $\mathrm{Mg}$-numbers and are enriched in the hygromagmatophile trace elements relative to normal MORB. They are similar in composition to evolved basalts erupted on islands in the major ocean basins.

Trace-element analyses of 36 representative lavas from the three major basalt provinces (tholeiitic, high-alumina, alkalic) of Japan are compared with the Leg 58 basalts. Variations among the elements $\mathrm{La}, \mathrm{Ba}, \mathrm{Th}$, and $\mathrm{Ta}$ discriminate between tholeiitic basalts formed at oceanic spreading centers and island arcs. In contrast, alkalic basalts associated with island arcs and oceanic crust cannot be distinguished using these elements. The geuchemical data are used in a discussion of the differences in composition of mantle sources involved in island-arc and ocean-crust magma genesis. A model invoking a variably veined mantle source is preferred to mantle-plume models for explaining mantle source inhomogeneities.
\end{abstract}

\section{INTRODUCTION}

Deep Sea Drilling Project Leg 58 drilled five sites in the north Philippine Sea to examine the geological history of the marginal ocean basin behind the IwoJima and Bonin Island arcs (Figure 1). One objective was to establish the range of basalt types erupted in this basin and compare them with basalts from other tectonic environments. Previous studies of the petrology and geochemistry of basalts dredged from other backarc basins, for example the Mariana Trough (Hart et al., 1972), the West Mariana Basin (Dietrich et al., 1978), the Lau Basin (Hawkins, 1976; Gill, 1976), the East Scotia Sea (Tarney et al., 1977; Saunders and

\footnotetext{
${ }^{1}$ Department of Geological Sciences, University of Birmingham, U. K.

${ }^{2}$ Laboratoire de Géochimie Comparée et Systématique UER des Sciences de la Terre et Institut de Physique du Globe, Université Pierre et Marie Curie, Paris, France and Laboratoire Pierre Süe, Groupe des Sciences de la Terre, CEN Saclay, Gif sur Yvette, France.
}

Tarney, 1979), suggest that these extensional areas are formed of oceanic crust and include basalts which are broadly similar in major- and trace-element compositions to MORB.

It has recently become clear (Wood et al., 1979a; Sun et al., 1979) that a range of basalt types are erupted at mid-ocean ridges, and it is now necessary to qualify the term "MORB" accordingly. In this report we will follow the classification of Sun et al. (1979), dividing MORB into three types, which we will distinguish by the prefixes "N," "E," and "T.", N-type MORB is the most abundant and so-called "normal" type, consisting of tholeiites with very low abundances of the hygromagmatophile (HYG) or incompatible elements, and with narrow ranges of HYG-element ratios (e.g., $\mathrm{Rb} / \mathrm{Sr}$ $<0.01 ; \mathrm{Th} / \mathrm{U} \sim 2$ ) and radiogenic to non-radiogenic isotopes of $\mathrm{Pb}$ (e.g., ${ }^{206} \mathrm{~Pb} /{ }^{204} \mathrm{~Pb}=17.75$ to 18.75 ), $\mathrm{Nd}$ $\left({ }^{143} \mathrm{Nd} /{ }^{144} \mathrm{Nd}=0.5131\right.$ to 0.5133$)$, and $\mathrm{Sr}\left({ }^{87} \mathrm{Sr} /{ }^{86} \mathrm{Sr}=\right.$ 0.7023 to 0.7027$)$. E-type MORB is erupted at hot-spot areas and consists of alkalic and tholeiitic basalts with high abundances of the HYG elements and enriched in 


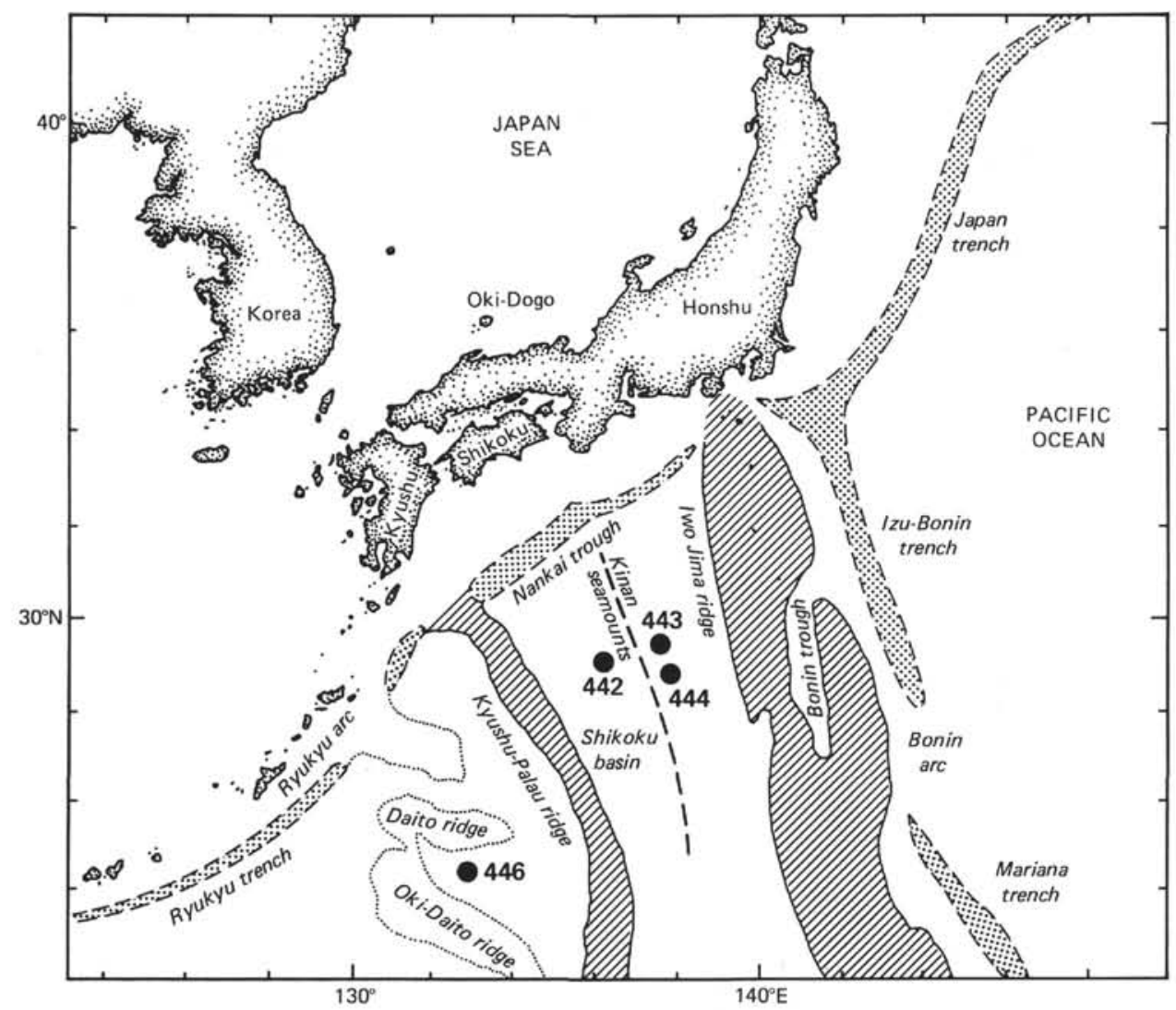

Figure 1. Sketch map of the Pacific Ocean near Japan, showing locations of the DSDP Leg 58 sites from which basalt was recovered. The main tectonic features of this region have been outlined.

the light rare-earth elements (REE) relative to chondrites (i.e., $\mathrm{La}_{\mathrm{N}} / \mathrm{Sm}_{\mathrm{N}}>1$ ). E-type MORB also has higher ratios of radiogenic to non-radiogenic isotopes of $\mathrm{Pb}$ (e.g., ${ }^{206} \mathrm{~Pb} / 204 \mathrm{~Pb}=18.5$ to 21$)$ and $\mathrm{Sr}\left({ }^{87} \mathrm{Sr} / 86 \mathrm{Sr}\right.$ $>0.7030)$, but lower $\mathrm{Nd}$-isotope ratios $\left({ }^{143} \mathrm{Nd} /{ }^{144} \mathrm{Nd}=\right.$ 0.5125 to 0.5130 ) than N-type MORB. E-type MORB may have $\mathrm{Fe}$ and $\mathrm{Ti}$ contents higher (e.g., Iceland) or lower (e.g., $45^{\circ} \mathrm{N}$ Mid-Atlantic Ridge) than N-type MORB with the same $\mathrm{Mg} / \mathrm{Fe}$ ratio. T-type MORB consists of tholeiites with HYG-element and radiogenicisotope compositions transitional (e.g., Reykjanes Ridge) between the other two types. The data used to characterize these MORB types come from several sources (see Wood et al., 1979, and Sun et al., in press, for references).

Published analyses of basalts from back-arc basins show that all types of MORB can be erupted in this environment. In addition, some basalts are transitional in composition between N-type MORB and island-arc tholeiites (viz., low abundances of the refractory HYG elements, but high abundances of the volatile HYG elements $-\mathrm{K}, \mathrm{Ba}, \mathrm{Sr}-$ and high $\mathrm{Sr}$-isotope ratios), for example, dredge 24 in the East Scotia Sea (Tarney et al., 1977; Hawkesworth et al., 1978; Saunders and Tarney, 1979). Moreover, some basalts erupted in the ensialic back-arc basin forming Bransfield Strait are transitional between $\mathrm{N}$-type MORB and calc-alkalic tholeiites
(Weaver et al., 1979). It seems that a component derived from the sources of island-arc or calc-alkalic lava series may be involved in basalt genesis in some back-arc basins. The proximity of island arcs and (or) active continental margins means that lavas derived from the respective series may be intimately associated with MORB types, especially in the oldest parts of the marginal basins. For these reasons, it is necessary to know the nature of the chemical variations in the surrounding island-arc and (or) calc-alkalic lava series when studying the chemistry of back-arc-basin basalts. We have therefore studied the DSDP Leg 58 samples in conjunction with the alkalic, calc-alkalic, and tholeitic series of Japan.

\section{TECTONIC SETTING AND SITE LOCATION}

\section{Shikoku Basin}

Three sites $(442,443$, and 444$)$ were drilled in the Shikoku Basin (Figure 1), an inter-arc basin lying between the Kyushu-Palau Ridge (an extinct arc) and the active Iwo Jima Ridge (a composite arc consisting of the Iwo Jima Ridge and Bonin Ridge, separated by the Bonin Trough - possibly an incipient back-arc basin), which are both underlain by continental crust (Murauchi et al., 1968). Seismic studies show that the Shikoku Basin is floored by oceanic crust (Katsumata 
and Sykes, 1969), with an axial zone showing the high heat flow and topography characteristic of many active spreading centers (Kobayashi and Isezaki, 1976). Linear magnetic anomalies parallel to the bounding arcs support sea-floor-spreading models for the formation of the basin, although the spreading may not have been symmetrical (Watts and Weissel, 1975). This extensional event began about $25 \mathrm{Ma}$ and caused the separation of the Kyushu-Palau and Iwo Jima Ridges. Studies of paleomagnetic inclinations and the distribution of sediment types indicate that the Shikoku Basin has drifted northward at about $3 \mathrm{~cm}$ per year for the last $15 \mathrm{~m} . \mathrm{y}$. and has been subducted at the Ryukyu Trough beneath Japan (Karig, 1975).

Site 442 is situated on marine magnetic anomaly 6 , about $50 \mathrm{~km}$ west of the axial zone of the basin; 188.4 meters of highly vesicular, aphyric basalt were drilled. Site 443 is situated on marine magnetic anomaly $6 \mathrm{~A}$, about $95 \mathrm{~km}$ east of the axial zone, on the same flow line (perpendicular to the spreading axis) as Site $442 ; 122$ meters of predominantly aphyric basalt were drilled. Site 444 is also situated on marine magnetic anomaly $6 \mathrm{~A}$, but about $100 \mathrm{~km}$ south of Site $443 ; 44.5$ meters of basalt (two sills) were drilled.

\section{Daito Ridge and Basin Province}

This province is located west of the Kyushu-Palau Ridge and east of the Ryukyu Trench (Figure 1). The province consists of a series of basins and remnant arcs (Karig, 1975) which have drifted some $1000 \mathrm{~km}$ northward in the past $52 \mathrm{~m} . \mathrm{y}$. as a result of sea-floor spreading in the west Philippine Basin. The tectonic history of this area is complex and controversial (cf. Klein and Kobayashi, this volume).

Site 446 is in the Daito Basin between the Daito and Oki-Daito Ridges; basement was not reached, but the lower 256 meters of the sedimentary section were intruded by at least 23 basalt sills. The basement is thought to have an early-Eocene age.

\section{SAMPLING AND ANALYTICAL TECHNIQUES}

In this study we have combined data obtained by $\mathrm{X}$-ray fluorescence (XRF) at Birmingham and instrumental neutron-activation analysis (INAA) at Saclay. Data quoted for the major-element oxides, $\mathrm{Zn}$, $\mathrm{Ga}, \mathrm{Sr}, \mathrm{Y}, \mathrm{Zr}, \mathrm{Nb}, \mathrm{Ba}$, and $\mathrm{Ce}$ were obtained by the XRF method of Tarney et al. (1979a). Data quoted for $\mathrm{Na}_{2} \mathrm{O}, \mathrm{Sc}, \mathrm{Cr}, \mathrm{Ni}, \mathrm{Rb}, \mathrm{Cs}, \mathrm{La}, \mathrm{Eu}, \mathrm{Tb}, \mathrm{Hf}$, Th, and $\mathrm{U}$ were obtained by the non-destructive INAA method of Chayla et al. (1973). Ta and Co were also determined, but unfortunately the rock powders used had been crushed in the tungsten-carbide shatterbox on board Glomar Challenger, which severely contaminates for these elements. The $\mathrm{Ta}$ and $\mathrm{Co}$ data are therefore not presented in this report.

Fifty-one samples were selected for INAA from representative sections of the Leg 58 cores. Petrographic data from shipboard studies and the complete set of XRF data (Marsh et al., this volume) were used to select these samples. It is the geochemical variation displayed by these 51 samples that we present here. In addition, 36 samples from well-studied parts of Japan and the Iwo Jima Ridge have been studied by INAA. These samples come from:

1. The tholeiitic or pigeonitic series of the Hakone region (Kuno, 1950; Fujimaki, 1975) and the island of Oshima at the northern end of the Iwo Jima Ridge (Kuno, 1958; 1960).

2. The high-alumina basalt and associated calcalkalic or hypersthenic series of Omuro-yama volcano of the Izu Peninsula (Kuno, 1954; 1966); Fuji; and the Asama volcano, central Honshu.

3. The alkalic series of Dogo, one of the Oki Islands in the Sea of Japan (Uchimizu, 1966; Nagasawa, 1973).

\section{RESULTS}

Representative major- and trace-element analyses of the geochemical units distinguished in the Leg 58 cores are given in Table 1, and the INAA results for all the 51 samples studied are given in Table 2. Marsh et al. (this volume) give complete XRF analyses for these samples.

Leg 58 major- and trace-element concentrations are plotted against the atomic ratio $\mathrm{Mg} /\left(\mathrm{Mg}+\mathrm{Fe}^{2+}\right)$, (where $\mathrm{Fe}^{2+}$ is calculated assuming an $\mathrm{Fe}_{2} \mathrm{O}_{3} / \mathrm{FeO}$ ratio of 0.15 ) in Figures 2 to 4 . The sub-alkaline basalts from Sites 442 and 443 form a coherent group in these diagrams, showing systematic decreases in $\mathrm{MgO}, \mathrm{Cr}$, and $\mathrm{Ni}$, and increases in $\mathrm{FeO}^{*}$ and the HYG elements with decrease in the ratio $\mathrm{Mg} /\left(\mathrm{Mg}+\mathrm{Fe}^{2+}\right)$. The upper sill at Site 444 (unit 444-1) is an alkali basalt with a relatively high $\mathrm{Mg} /\left(\mathrm{Mg}+\mathrm{Fe}^{2+}\right)$ ratio (>0.63). It can be distinguished readily from the sub-alkaline basalts of Sites 442 and 443 by its low total $\mathrm{Fe}$ (as $\mathrm{FeO}$ ) and $\mathrm{CaO}$ contents, and by its high $\mathrm{Na}_{2} \mathrm{O}$ and HYG-element contents - especially those HYG elements with the lowest bulk solid/liquid partition coefficients $(D)$ in basaltic systems (e.g., $\mathrm{Ba}, \mathrm{Th}, \mathrm{Nb}, \mathrm{K}$, and $\mathrm{La}$ - referred to here as the more-HYG elements). The sub-alkaline basalt forming the lower sill at Site 444 (unit 444-2) is similar to the basalts of Sites 442 and 443 , but has slightly higher contents of the more-HYG elements.

Basalts from the Daito Basin (Site 446) are readily distinguished from the Shikoku Basin basalts (Figures 2 and 3). They have lower $\mathrm{MgO}$ and $\mathrm{Mg} /\left(\mathrm{Mg}+\mathrm{Fe}^{2+}\right)$ ratios (except for the cumulates of unit 446-5), and significantly higher total $\mathrm{Fe}$ (as $\mathrm{FeO}$ ) and $\mathrm{TiO}_{2}$ (as much as 14 and 5 wt. $\%$, respectively) and HYG-element abundances, which broadly increase with decreasing $\mathrm{Mg} / \mathrm{Mg}$ $+\mathrm{Fe}^{2+}$ ) ratio. The basalts vary from quartz-normative tholeiites to nepheline-normative, kaersutite-bearing alkali basalts. The alkali basalts have significantly higher contents of $\mathrm{Ba}, \mathrm{K}$, and $\mathrm{Sr}$, but lower total $\mathrm{Fe}$ (as $\mathrm{FeO}$ ) and $\mathrm{MgO}$ for given $\mathrm{Mg} /\left(\mathrm{Mg}+\mathrm{Fe}^{2+}\right)$ ratios (except cumulate unit 446-5) than the tholeiitic-basalts. The Site 446 basalts have suffered variable degrees of postmagmatic alteration, but, although $\mathrm{K}, \mathrm{Sr}$, and $\mathrm{Ba}$ may be mobilized during hydrothermal alteration (Hart, 1971; Wood et al., 1976), the differences observed between the alkalic and tholeiitic units of Site 446 are considered to be primary, for two reasons: (1) K, Sr, and $\mathrm{Ba}$ are enriched by more than a factor of two in the alkali basalts, and in some cases the lavas with the highest 
TABLE 1

Representative Analyses of Leg 58 Basalts, Compared with Typical Depleted, Transitional, and Enriched Atlantic Basaltsa

\begin{tabular}{|c|c|c|c|c|c|c|c|c|c|c|c|}
\hline \multirow[b]{3}{*}{ Component ${ }^{b}$} & \multicolumn{11}{|c|}{ Shikoku Basin } \\
\hline & \multicolumn{4}{|c|}{ Site 442} & \multicolumn{5}{|c|}{ Site 443} & \multicolumn{2}{|c|}{ Site 444} \\
\hline & $442-1$ & $442-2$ & $442-3$ & $442-4$ & $443-1$ & $443-2$ & $443-3$ & $443-4$ & $443-5$ & $444-1$ & $444-2$ \\
\hline $\mathrm{SiO}_{2}$ & 49.87 & 49.78 & 49.36 & 50.24 & 49.54 & 49.53 & 50.44 & 48.75 & 48.42 & 50.26 & 50.25 \\
\hline $\mathrm{TiO}_{2}$ & 1.23 & 1.55 & 1.26 & 1.59 & 1.56 & 1.31 & 1.93 & 1.11 & 1.11 & 1.94 & 1.61 \\
\hline $\mathrm{Al}_{2} \mathrm{O}_{3}$ & 15.91 & 16.11 & 15.81 & 16.16 & 16.67 & 16.26 & 14.91 & 15.92 & 15.59 & 16.21 & 16.11 \\
\hline $\mathrm{Fe}_{2} \mathrm{O}_{3} \mathrm{c}$ & 1.01 & 1.23 & 1.12 & 1.23 & 1.24 & 1.21 & 1.16 & 1.12 & 1.13 & 0.95 & 1.21 \\
\hline $\mathrm{FeO}$ & 6.72 & 8.20 & 7.44 & 8.23 & 8.25 & 8.07 & 7.71 & 7.44 & 7.51 & 6.31 & 8.05 \\
\hline $\mathrm{MnO}$ & 0.10 & 0.16 & 0.13 & 0.19 & 0.18 & 0.15 & 0.10 & 0.15 & 0.15 & 0.15 & 0.17 \\
\hline $\mathrm{MgO}$ & 7.63 & 5.89 & 6.26 & 5.46 & 6.54 & 7.61 & 9.33 & 9.56 & 10.09 & 6.25 & 6.87 \\
\hline $\mathrm{CaO}$ & 11.43 & 11.97 & 11.31 & 12.13 & 11.56 & 11.76 & 9.26 & 11.06 & 10.65 & 8.59 & 11.36 \\
\hline $\mathrm{Na}_{2} \mathrm{O}$ & 3.38 & 3.25 & 3.05 & 3.62 & 3.10 & 3.17 & 3.47 & 2.93 & 2.67 & 4.00 & 3.22 \\
\hline $\mathrm{K}_{2} \mathrm{O}$ & 0.25 & 0.33 & 0.42 & 0.38 & 0.17 & 0.11 & 0.26 & 0.07 & 0.11 & 2.31 & 0.16 \\
\hline $\mathrm{P}_{2} \mathrm{O}_{5}$ & 0.14 & 0.22 & 0.15 & 0.20 & 0.18 & 0.14 & 0.20 & 0.11 & 0.12 & 0.39 & 0.23 \\
\hline L.o.i. & n.d. & n.d. & n.d. & n.d. & n.d. & n.d. & n.d. & n.d. & n.d. & n.d. & n.d. \\
\hline Total & 97.67 & 98.69 & 96.31 & 99.43 & 98.99 & 99.32 & 98.77 & 98.22 & 97.55 & 97.36 & 99.24 \\
\hline $\mathrm{Mg} /\left(\mathrm{Mg}+\mathrm{Fe}^{2+}\right)$ & 0.669 & 0.561 & 0.599 & 0.541 & 0.585 & 0.626 & 0.683 & 0.695 & 0.705 & 0.638 & 0.603 \\
\hline Total $\mathrm{Fe}$ as $\mathrm{FeO}$ & 7.63 & 9.30 & 8.45 & 9.34 & 9.37 & 9.16 & 8.75 & 8.45 & 8.52 & 7.16 & 9.13 \\
\hline Sc & 37.2 & 37.1 & 34.5 & 41.5 & 34.4 & 36.2 & 39.6 & 31.2 & 30.5 & 38.8 & 35.9 \\
\hline $\mathrm{Cr}$ & 216 & 193 & 64 & 91 & 204 & 262 & 229 & 251 & 272 & 130 & 228 \\
\hline $\mathrm{Ni}$ & 113 & 73 & 44 & 71 & 58 & 133 & 127 & 197 & 186 & 32 & 60 \\
\hline $\mathrm{Zn}$ & 70 & 105 & 109 & 84 & 79 & 107 & 86 & 61 & 62 & 79 & 63 \\
\hline $\mathrm{Ga}$ & 19 & 21 & 20 & 24 & 22 & 17 & 21 & 17 & 17 & 18 & 20 \\
\hline $\mathrm{Rb}$ & 2 & 5 & 8 & 14 & 2 & 2 & 3 & 2 & 2 & 16 & 2 \\
\hline $\mathrm{Sr}$ & 183 & 175 & 204 & 186 & 151 & 158 & 154 & 140 & 137 & 391 & 160 \\
\hline Y & 23 & 37 & 30 & 38 & 35 & 30 & 40 & 25 & 26 & 38 & 40 \\
\hline $\mathrm{Zr}$ & 91 & 116 & 93 & 123 & 121 & 95 & 138 & 80 & 78 & 209 & 141 \\
\hline $\mathrm{Nb}$ & 1 & 4 & $<1$ & 3 & 5 & 3 & 7 & - & 1 & 31 & 7 \\
\hline Cs & 0.07 & 0.24 & 0.37 & 1.7 & 0.04 & 0.03 & 0.05 & 0.04 & 0.03 & 0.14 & 0.06 \\
\hline $\mathrm{Ba}$ & 32 & 24 & 34 & 34 & 42 & 18 & 60 & 19 & 25 & 177 & 71 \\
\hline $\mathrm{La}$ & 2.9 & 4.0 & 3.7 & 4.6 & 4.8 & 3.3 & 5.6 & 2.4 & 2.4 & 19.3 & 6.2 \\
\hline $\mathrm{Ce}$ & 12 & 18 & 18 & 15 & 16 & 12 & 18 & 11 & 11 & 42 & 20 \\
\hline Eu & 1.15 & 1.48 & 1.15 & 1.41 & 1.41 & 1.29 & 1.66 & 1.09 & 1.15 & 1.95 & 1.56 \\
\hline $\mathrm{Tb}$ & 0.61 & 0.81 & 0.68 & 0.83 & 0.83 & 0.74 & 0.91 & 0.58 & 0.56 & 0.86 & 0.81 \\
\hline Hf & 0.39 & 3.00 & 2.23 & 3.10 & 2.99 & 2.44 & 3.61 & 1.93 & 1.80 & 4.05 & 3.39 \\
\hline Th & 0.20 & 0.25 & 0.38 & 0.29 & 0.34 & 0.18 & 0.47 & 0.13 & 0.19 & 2.40 & 0.70 \\
\hline U & 0.39 & - & 0.18 & 0.26 & - & - & 0.11 & - & - & 0.92 & - \\
\hline
\end{tabular}

${ }^{\mathrm{a}}$ Units represented by samples as follows: $442-1=442 \mathrm{~B}-5-2,1-5 \mathrm{~cm} ; 442-2=442 \mathrm{~B}-11-2,70-73 \mathrm{~cm} ; 442-3=442 \mathrm{~B}-16-2,15-18 \mathrm{~cm} ; 442-4$ $=442 \mathrm{~B}-19-2,51-54 \mathrm{~cm} ; 443-1=443-50-2,14-16 \mathrm{~cm} ; 443-2=443-54-4,106-109 \mathrm{~cm} ; 443-3=443-58-4,30-32 \mathrm{~cm} ; 443-4=443-61-1$, 93-95 cm; 443-5 = 443-64-2, 97-100 cm; 444-1 = 444A-20-1, 73-77 cm; 444-2 = 444A-25-1, $118-123 \mathrm{~cm} ; 446-1=446-42, C C, 24-26 \mathrm{~cm}$; $446-4=446 \mathrm{~A}-11-2,27-30 \mathrm{~cm} ; 446-5=446 \mathrm{~A}-12-4,36-39 \mathrm{~cm} ; 446-6=446 \mathrm{~A}-15-3,75-77 \mathrm{~cm} ; 446-7 \mathrm{a}=446 \mathrm{~A}-18-4,85-87 \mathrm{~cm} ; 446-8=$ $446 \mathrm{~A}-21-4,79-81 \mathrm{~cm} ; 446-9=446 \mathrm{~A}-22-1,29-31 \mathrm{~cm} ; 446-10=446 \mathrm{~A}-22-2,82-84 \mathrm{~cm} ; 446-11=446 \mathrm{~A}-23-2,52-53 \mathrm{~cm}$.

bajor element oxides in wt. \%; trace elements in ppm.

${ }_{d} \mathrm{Fe}_{2} \mathrm{O}_{3}$ values are calculated assuming $\mathrm{Fe}_{2} \mathrm{O}_{3} / \mathrm{FeO}=0.15$.

$\mathrm{d}_{\mathrm{A}}=$ typical "depleted" MORB. Major elements from Engel et al. (1965); trace elements from Sun et al. (1979) and Bougault et al. (1979); but typical values are chosen for $\mathrm{Sc}, \mathrm{Cr}$, and $\mathrm{Ni}$.

B = "transitional" MORB, Reykjanes Ridge, Site 409, Unit 3 (Wood et al., 1979a).

C = "enriched" ferrobasalt, Eldgiá, Iceland: Sample ISL79 (Wood et al., 1979b).

$\mathrm{D}=$ "enriched" alkali basalt, Faial, Azores: Sample FA47 (Joron et al., in prep.).

abundances are petrographically the freshest; (2) these variations correlate with smaller major-element variations.

\section{BASALT STRATIGRAPHY OF THE LEG 58 SITES}

The available major- and trace-element data can be used to divide the basalt sections into chemical units consisting of one or several successive flows or sills derived from liquid of the same composition (Marsh et al., this volume). The breaks between the units generally correspond to changes in petrography and magnetic in- clinations. The units have been numbered in ascending order with increasing depth. Where a significant change in chemistry occurs without change in petrography or magnetic inclination, the units are divided into sub-units labeled $a$ and $b$. The extent and petrography of these units are summarized in Table 3.

The chemical units at Sites 442 and 443 cannot be distinguished in Figures 2 to 4 . A plot of concentrations of a more-HYG element versus a less-HYG element, e.g., Th versus $\mathrm{Hf}$ (Figure 5), distinguishes the chemical units at these sites most clearly. The units of Site 442 
TABLE 1 - Continued

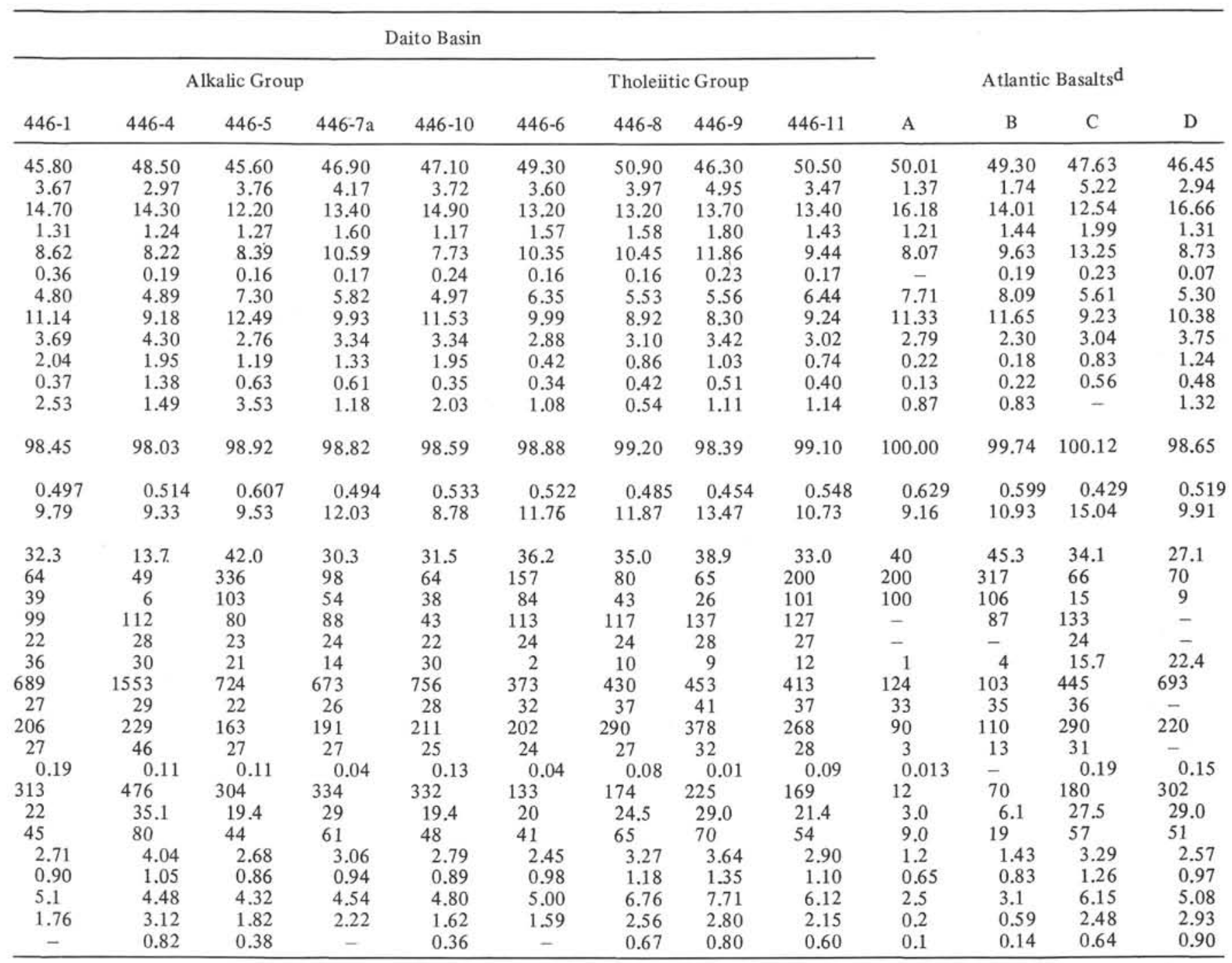

display a relatively restricted range of abundances and ratios of the HYG elements, although the one sample analyzed from unit 442-3 is enriched in Th relative to the other samples. Additional analyses are required from this unit in order to confirm that the high Th is a characteristic of the parental magma from which this unit was derived. Unit $442-1$ is the most primitive and unit 442-4 the most evolved basalt recovered at this site; both have the same $\mathrm{Th} / \mathrm{Hf}$ ratios, and we interpret them as being derived from similar parental magma by crystal fractionation processes.

The five units of Site 443 show a slightly greater range of HYG-element ratios than those at Site 442, although they have very similar overall compositions. The five units can be placed into three groups with different $\mathrm{Th} / \mathrm{Hf}$ ratios. Units $443-2$ and $443-4$ have the lowest values of these ratios. Units 443-1 and 443-5, the top and bottom units respectively, have intermediate values. Unit 443-3 has the highest values of these ratios at this site. As both elements involved in these ratios have $D$ values significantly less than 1 , their values can- not be readily changed by crystal-fractionation processes, unless garnet occurs as a liquidus phase, or significant amounts of clinopyroxene are removed from the system, or one invokes an open-system magma chamber from which very small batches of magma (relative to the volume of the magma chamber) are repeatedly extracted. While all three of these processes can significantly increase the more-HYG to less-HYG element ratios in the residual liquid, in doing so they will (except for garnet fractionation) cause a significant increase in the absolute abundance of these elements (especially the more-HYG elements) in the residual liquid. Although the occurrence of a high-pressure crystal-fractionation event involving garnet or eclogite (O'Hara, 1975) which has been obscured subsequently by the equilibration of the residual liquid at low pressure cannot be ruled out, we consider that the range of HYG element ratios observed at Site 443 can be explained more reasonably by partial-melting processes. In this case, the parental magma from which units 443-2 and 443-4 were derived by crystal fractionation was produced by higher degrees 
TABLE 2

Instrumental Neutron-Activation Analyses of 51 Basalt Samples from Leg $58^{\mathrm{a}}$

\begin{tabular}{|c|c|c|c|c|c|c|c|c|c|c|c|c|c|}
\hline $\begin{array}{c}\text { Sample } \\
\text { (interval in } \mathrm{cm} \text { ) }\end{array}$ & $\mathrm{Na}_{2} \mathrm{O}$ & $\mathrm{Fe}_{2} \mathrm{O}_{3}$ & $\mathrm{Sc}$ & $\mathrm{Cr}$ & $\mathrm{Ni}$ & $\mathrm{Rb}$ & Cs & $\mathrm{La}$ & $\mathrm{Eu}$ & $\mathrm{Tb}$ & $\mathrm{Hf}$ & Th & $\mathrm{U}$ \\
\hline $442 \mathrm{~A}-31-1,85-89$ & 2.94 & 9.06 & 38.5 & 185 & 59 & 7.0 & 0.33 & 3.0 & 1.22 & 0.64 & 2.23 & 0.20 & - \\
\hline $34-1,78-82$ & 3.06 & 8.90 & 36.5 & 207 & 72 & 4.5 & 0.09 & 3.1 & 1.09 & 0.58 & 1.97 & 0.17 & 0.03 \\
\hline $442 \mathrm{~B}-3-3,140-143$ & 3.01 & 9.35 & 38.9 & 215 & 64 & 4.4 & 0.29 & 2.9 & 1.16 & 0.70 & 2.20 & 0.17 & 0.10 \\
\hline $4-3,21-23$ & 3.10 & 9.34 & 37.4 & 190 & 62 & 4.0 & 0.17 & 2.9 & 1.14 & 0.67 & 2.12 & 0.21 & - \\
\hline $5-2,1-5$ & 3.38 & 8.78 & 37.2 & 216 & 113 & 3.2 & 0.07 & 2.9 & 1.15 & 0.61 & 2.21 & 0.20 & 0.39 \\
\hline $8-1,32-36$ & 2.77 & 9.31 & 30.0 & 328 & 224 & - & 0.03 & 2.3 & 0.90 & 0.53 & 1.71 & 0.12 & - \\
\hline $8-5,74-79$ & 3.22 & 9.50 & 34.1 & 226 & 118 & - & 0.04 & 3.2 & 1.13 & 0.67 & 2.19 & 0.20 & - \\
\hline $8-7,104-108$ & 3.63 & 9.03 & 36.6 & 210 & 79 & 2.4 & 0.16 & 3.1 & 1.17 & 0.63 & 2.27 & 0.21 & - \\
\hline $10-1,110-114$ & 3.29 & 11.29 & 40.7 & 161 & 58 & 6.1 & 0.24 & 3.2 & 1.49 & 0.84 & 2.84 & 0.13 & - \\
\hline $11-2,70-73$ & 3.25 & 10.36 & 37.1 & 193 & 73 & - & 0.24 & 4.0 & 1.48 & 0.81 & 3.00 & 0.25 & - \\
\hline $16-2,15-18$ & 3.05 & 9.58 & 34.5 & 64 & 44 & 5.8 & 0.37 & 3.7 & 1.15 & 0.68 & 2.23 & 0.38 & 0.18 \\
\hline $19-2,51-54$ & 3.62 & 10.82 & 41.5 & 91 & 71 & 12.4 & 1.70 & 4.6 & 1.41 & 0.83 & 3.10 & 0.29 & 0.26 \\
\hline $443-50-2,14-16$ & 3.10 & 10.72 & 34.4 & 204 & 58 & - & 0.04 & 4.75 & 1.41 & 0.83 & 2.99 & 0.34 & - \\
\hline $53-2,117-119$ & 3.32 & 9.79 & 38.5 & 250 & 119 & 3.9 & 0.15 & 3.9 & 1.54 & 0.81 & 2.71 & 0.20 & - \\
\hline $54-4,106-109$ & 3.17 & 10.48 & 36.2 & 262 & 133 & - & 0.03 & 3.3 & 1.29 & 0.74 & 2.44 & 0.18 & - \\
\hline $55-2,115-117$ & - & 10.47 & 35.9 & 226 & 128 & 3.9 & 0.18 & - & 1.40 & 0.81 & 3.07 & 0.41 & - \\
\hline $56-3,115-117$ & - & 10.58 & 38.5 & 214 & 62 & 12.3 & 1.64 & - & 1.56 & 0.90 & 3.23 & 0.46 & - \\
\hline $58-3,29-31$ & - & 12.23 & 29.9 & 358 & 448 & - & 0.07 & - & 1.12 & 0.67 & 2.39 & 0.34 & - \\
\hline $58-4,30-32$ & 3.47 & 9.53 & 39.6 & 229 & 127 & - & 0.05 & 5.6 & 1.66 & 0.91 & 3.61 & 0.47 & 0.11 \\
\hline $59-3,101-103$ & - & 8.68 & 33.2 & 245 & 147 & - & 0.20 & - & 1.08 & 0.55 & 2.23 & 0.17 & - \\
\hline $60-4,0-3$ & 3.06 & 9.58 & 36.1 & 281 & 109 & - & 0.05 & 2.6 & 1.30 & 0.63 & 2.10 & 0.14 & - \\
\hline $61-1,93-95$ & 2.93 & 9.14 & 31.2 & 251 & 197 & - & 0.04 & 2.4 & 1.09 & 0.58 & 1.93 & 0.13 & - \\
\hline $62-2,27-29$ & 3.30 & 8.64 & 37.1 & 238 & 104 & 3.0 & 0.25 & 3.2 & -1.22 & 0.64 & 2.24 & 0.19 & - \\
\hline $64-2,97-100$ & 2.67 & 8.85 & 30.5 & 272 & 186 & - & 0.03 & 2.4 & 1.15 & 0.56 & 1.80 & 0.19 & - \\
\hline $64-4,32-35$ & 3.06 & 9.33 & 34.8 & 273 & 124 & 3.7 & 0.24 & 3.0 & 1.30 & 0.61 & 2.03 & 0.23 & - \\
\hline $444 \mathrm{~A}-20-1,22-27$ & 3.44 & 8.29 & 30.0 & 197 & 152 & 10.2 & 0.37 & 14.1 & 1.47 & 0.64 & 2.88 & 1.63 & 0.48 \\
\hline $20-1,73-77$ & 4.00 & 8.28 & 38.8 & 130 & 32 & 13.3 & 0.14 & 19.3 & 1.95 & 0.86 & 4.05 & 2.40 & 0.92 \\
\hline $20-4,37-39$ & 3.95 & 8.42 & 28.0 & 226 & 203 & 16.0 & 0.41 & 12.3 & 1.29 & 0.57 & 2.74 & 1.48 & 0.47 \\
\hline $25-1,118-123$ & 3.22 & 10.42 & 35.9 & 228 & 60 & - & 0.06 & 6.2 & 1.56 & 0.81 & 3.39 & 0.70 & - \\
\hline $27-2,62-67$ & 3.13 & 8.96 & 29.3 & 236 & 108 & - & 0.04 & 5.3 & 1.24 & 0.67 & 2.49 & 0.51 & - \\
\hline $27-5,68-72$ & 2.89 & 10.15 & 33.0 & 290 & 127 & 4.3 & 0.08 & 5.9 & 1.45 & 0.76 & 2.96 & 0.54 & - \\
\hline $446-41, C C, 20-24$ & - & 10.74 & 31.9 & 62 & 39 & 35.8 & 0.23 & - & 2.74 & 1.00 & 5.2 & 1.78 & - \\
\hline $42, \mathrm{CC}, 24-26$ & - & 11.79 & 32.3 & 64 & 39 & 31.8 & 0.19 & - & 2.71 & 0.90 & 5.1 & 1.76 & - \\
\hline $44-1,19-21$ & - & 13.72 & 34.0 & 140 & 85 & - & - & - & 2.55 & 1.29 & 6.29 & 2.58 & - \\
\hline $446 \mathrm{~A}-6-2,34-39$ & - & 14.67 & 33.6 & 157 & 85 & 18.2 & 0.17 & - & 3.06 & 1.19 & 6.88 & 2.89 & - \\
\hline $9-2,120-122$ & - & 13.52 & 34.5 & 94 & 47 & 11.5 & 0.08 & - & 3.29 & 1.48 & 6.95 & 2.75 & - \\
\hline $11-2,27-30$ & 4.30 & 11.29 & 13.7 & 49 & 6.2 & 28 & 0.11 & 35.1 & 4.04 & 1.05 & 4.48 & 3.12 & 0.82 \\
\hline $12-1,59-62$ & - & 13.42 & 40.3 & 1012 & 304 & 16.8 & 0.10 & - & 2.72 & 0.80 & 4.0 & 1.56 & - \\
\hline $12-4,36-39$ & 2.73 & 11.50 & 42.0 & 336 & 103 & 19 & 0.11 & 19.4 & 2.68 & 0.86 & 4.32 & 1.82 & 0.38 \\
\hline $13-1,109-111$ & - & 13.73 & 22.0 & 840 & 723 & 5.0 & 0.24 & - & 1.77 & 0.57 & 3.26 & 1.55 & - \\
\hline $15-3,75-77$ & - & 13.39 & 36.2 & 157 & 84 & 4.8 & 0.04 & - & 2.45 & 0.98 & 5.0 & 1.59 & - \\
\hline $16-2,72-74$ & - & 12.46 & 34.7 & 160 & 88 & - & 0.06 & - & 2.50 & 0.95 & 4.90 & 1.48 & - \\
\hline $18-4,85-87$ & - & 13.86 & 30.3 & 98 & 54 & 12.3 & 0.04 & - & 3.06 & 0.94 & 4.54 & 2.22 & - \\
\hline $19-2,54-56$ & - & 12.86 & 34.7 & 169 & 90 & 11.6 & 0.10 & - & 2.86 & 1.10 & 5.77 & 2.02 & - \\
\hline $21-4,79-81$ & 3.10 & 13.58 & 35.0 & 80 & 43 & 10 & 0.08 & 24.5 & 3.27 & 1.18 & 6.76 & 2.56 & 0.67 \\
\hline $22-1,29-31$ & 3.42 & 15.71 & 38.9 & 65 & 26 & 11 & 0.01 & 29.0 & 3.64 & 1.35 & 7.71 & 2.80 & 0.80 \\
\hline $22-2,82-84$ & 3.34 & 10.41 & 31.5 & 64 & 38 & 29 & 0.13 & 19.4 & 2.79 & 0.89 & 4.80 & 1.62 & 0.36 \\
\hline $23-2,52-53$ & 3.02 & 12.18 & 33.0 & 200 & 101 & 11 & 0.09 & 21.4 & 2.90 & 1.10 & 6.12 & 2.15 & 0.60 \\
\hline $24-4,73-76$ & 2.76 & 14.19 & 34.4 & 130 & 67 & 4 & 0.02 & 20.1 & 2.84 & 1.08 & 5.97 & 2.38 & 0.62 \\
\hline $26-3,46-48$ & 2.81 & 12.96 & 34.9 & 205 & 105 & 11 & 0.43 & 20.1 & 2.60 & 1.02 & 5.41 & 1.96 & 0.42 \\
\hline $27-2,94-98$ & 2.86 & 15.17 & 37.6 & 96 & 51 & 8 & - & 27.4 & 3.46 & 1.26 & 7.35 & 2.91 & 0.80 \\
\hline
\end{tabular}

${ }^{\mathrm{a}} \mathrm{Na}_{2} \mathrm{O}$ and $\mathrm{Fe}_{2} \mathrm{O}_{3}$ in wt. \%; remainder in ppm; $\mathrm{Fe}_{2} \mathrm{O}_{3}=$ total $\mathrm{Fe}$ as $\mathrm{Fe}_{2} \mathrm{O}_{3}$.

of partial melting than the parental magmas from which the other units were derived.

The interlayering of basalts derived from different parental magmas at Site 443 suggests that a large, continuous magma chamber underlying the spreading axis was not involved in the genesis of these basalts. A model invoking the existence of small magma chambers, discontinuous in space and time, can be reconciled more readily with the observed geochemical variation.

Figure 6 is a plot of Th versus Hf for all the Leg 58 samples analysed, with the chemical units of Sites 444 and 446 distinguished. All basalts from Sites 444 and 

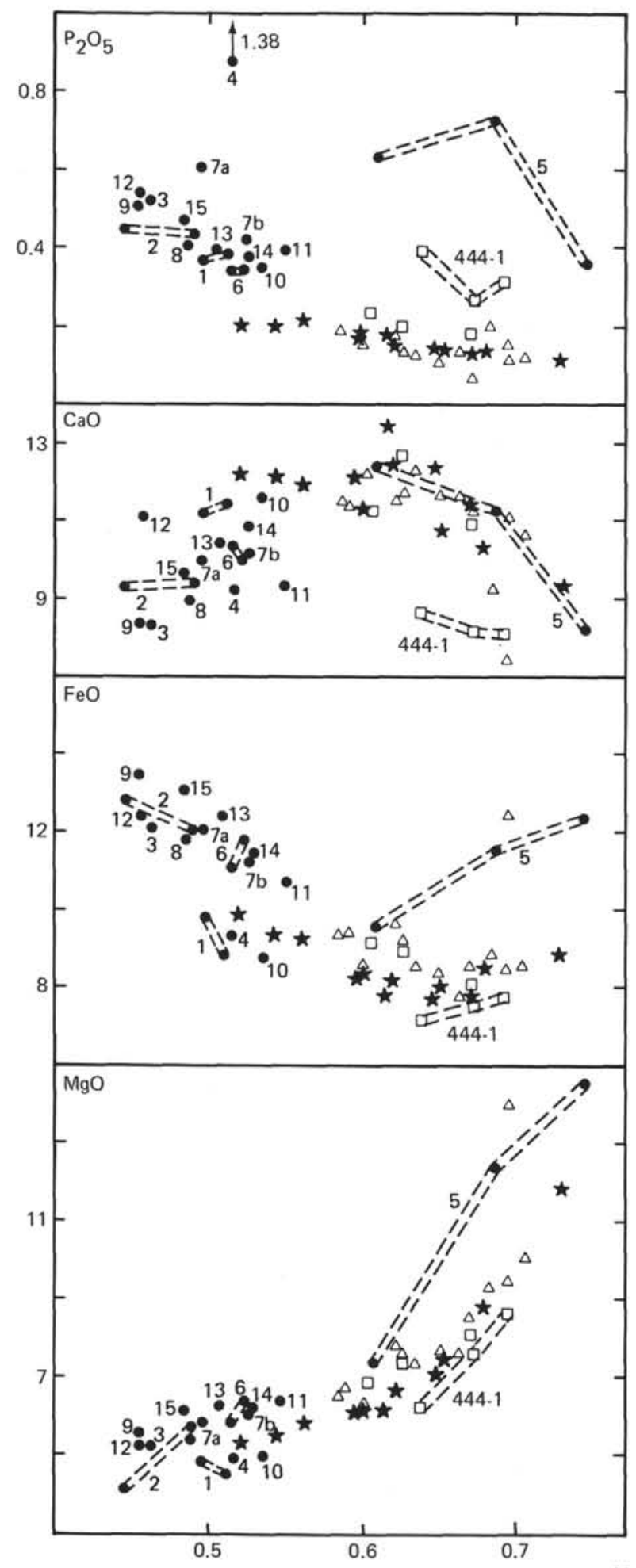

$\mathrm{Mg} /\left(\mathrm{Mg}+\mathrm{Fe}^{2+}\right)$

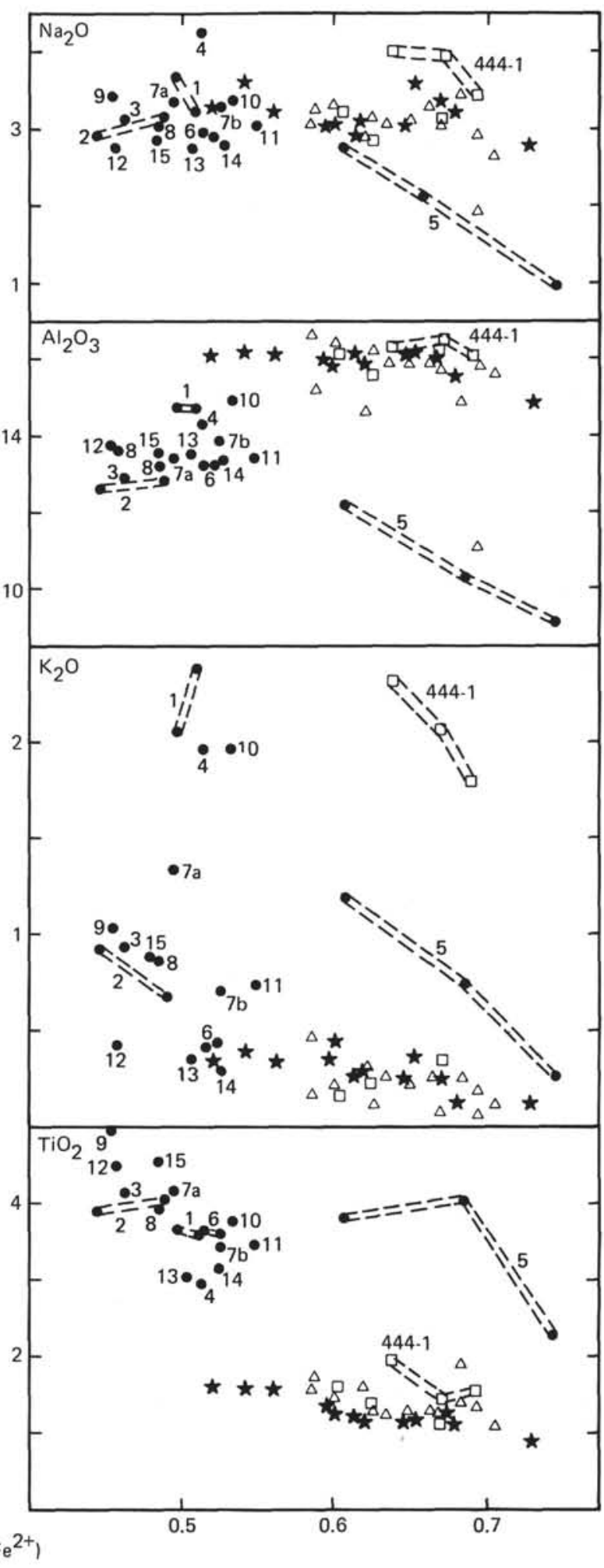

Figure 2. Major-element variation diagram for DSDP Leg 58 basalts. Stars represent Site 442, triangles Site 443, squares Site 444, closed circles Site 446. Numbers associated with these symbols refer to geochemical units (cf. Table 3). Numbers associated with arrows refer to oxide concentrations which plot outside the diagram. All major-element-oxide concentrations are in weight per cent. 


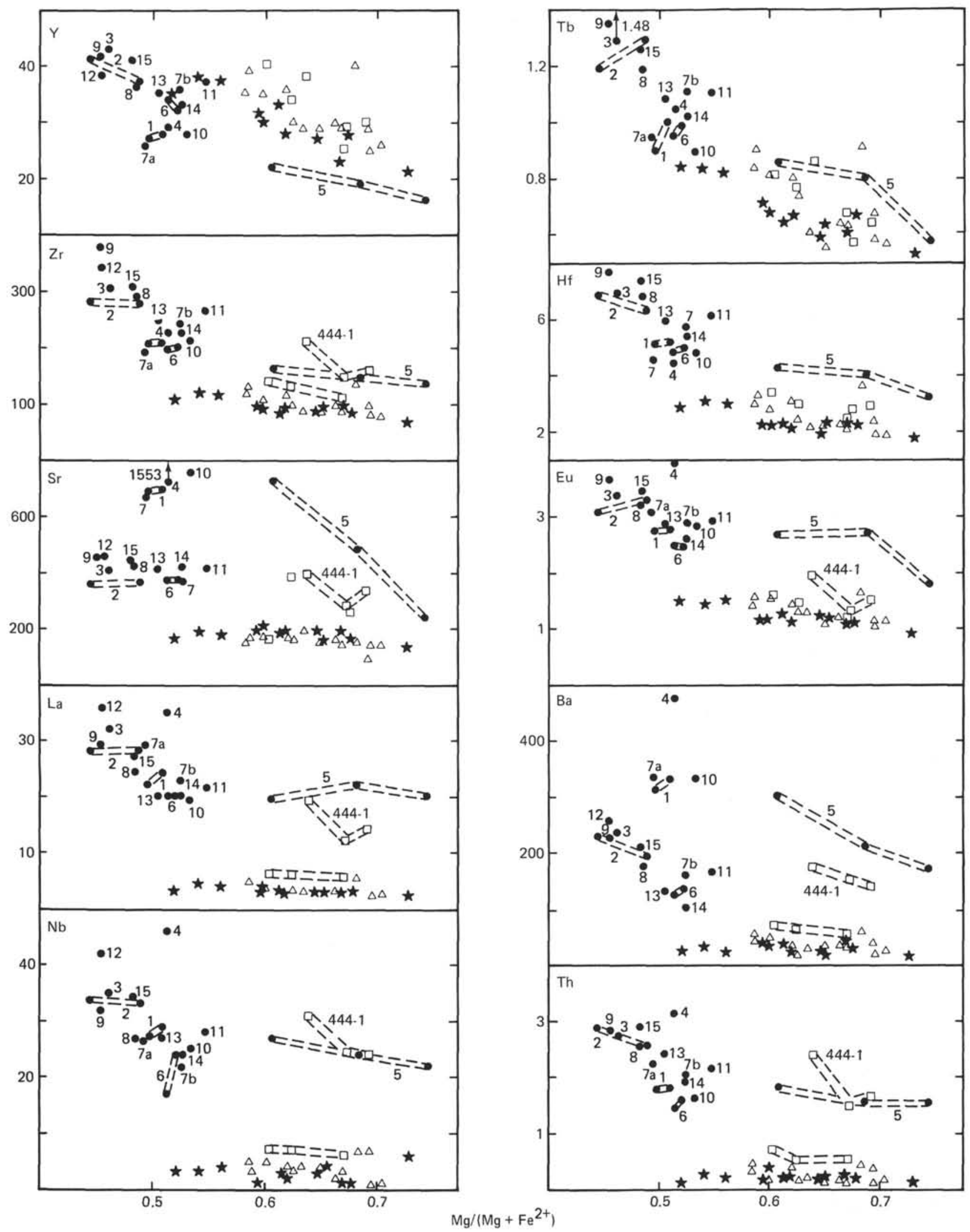

Figure 3. Hygromagmatophile-trace-element variation diagram for DSDP Leg 58 basalts. Symbols and numbers are used in the same sense as in Figure 2. All trace-element concentrations are in ppm. 


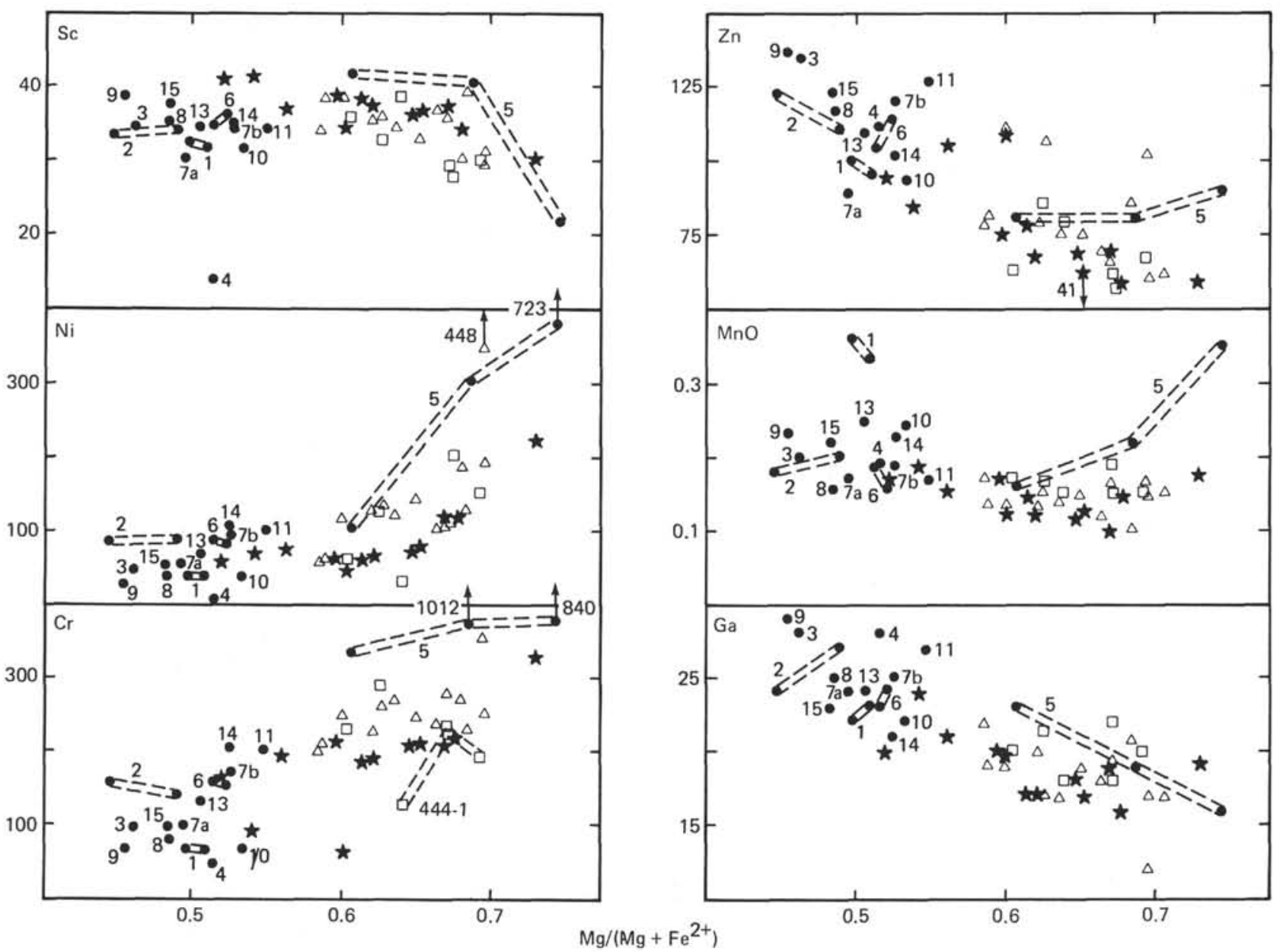

Figure 4. Ferromagnesian-trace-element variation diagram for DSDP Leg 58 basalts. Symbols and numbers are used in the same sense as in Figure 2. Concentrations of $\mathrm{MnO}$ are in weight per cent; all other elements are in ppm.

446 have higher Th/Hf ratios than those of Sites 442 and 443 . The two sills penetrated at Site 444 plot completely separately in Figure 6, as they do in Figures 2 and 3 , but unit $444-2$ plots close to the 442 and 443 basalts. The basalt stratigraphy at Site 446 is much more complicated because of the large number of sills sampled. The 15 geochemical units all have high $\mathrm{Th} / \mathrm{Hf}$ ratios and, except for unit 446-4, conform to a single trend on Figure 6. Nevertheless, as pointed out above, the geochemical units can be divided into two distinct groups: a tholeiitic group (units $446-2,-3,-6,-7 b,-8,-9,-11,-12$, $-13,-14,-15$ ) and an alkalic group (units $446-1,-4,-5$, $-7 \mathrm{a},-10)$, which are clearly interdigitated down-hole, although they could be related to separate phases of injection. Figure 7 is a plot of Ba versus Y, which discriminates between the two basalt groups. Units 446-4 and 446-5 can be distinguished from the other units of the alkalic group by their much higher $\mathrm{P}_{2} \mathrm{O}_{5}$ contents (Figure 2). These units are coarse grained and contain apatite as an accessory phase. The presence of cumulate apatite may explain the higher $\mathrm{Sr}, \mathrm{Th}, \mathrm{La}, \mathrm{Ba}, \mathrm{Eu}$, and $\mathrm{Tb}$ contents of unit 446-4.

\section{COMPARISONS BETWEEN LEG 58 BASALTS AND MORB TYPES}

In Table 1 we have included the major- and traceelement chemistry of average N-type MORB. Most of the sub-alkaline basalts from the Shikoku Basin are very similar to this average, but units $443-3$ and $444-2$ are less depleted in the more-HYG elements than N-type MORB. Unfortunately, the element ratios which are commonly used to discriminate $\mathrm{N}$-type MORB from the other MORB types (e.g., $\mathrm{K} / \mathrm{Rb}, \mathrm{Rb} / \mathrm{Sr}$, and $\mathrm{Th} / \mathrm{U}$ ) can be substantially modified by alteration processes, because of the mobility of all these elements (except Th). It is therefore necessary to use ratios of immobile or less-mobile HYG elements (e.g., Th/ $\mathrm{Hf}, \mathrm{Zr} / \mathrm{Nb}$, and $\mathrm{Ba} / \mathrm{La}$; we would have liked to use $\mathrm{La} / \mathrm{Ta}$ as well, but the contamination of the samples during crushing has precluded this). Units $443-3$ and $444-2$ are similar to 
TABLE 3

Delimitation and Petrography of Geochemical Units Distinguished in Leg 58 Cores

\begin{tabular}{llll}
\hline $\begin{array}{c}\text { Geochemical } \\
\text { Units }\end{array}$ & \multicolumn{1}{c}{ Core Intervals (lower limits) } & Lithologic Units a & \multicolumn{1}{c}{ Petrography } \\
\hline $442-1$ & $442 \mathrm{~A}$ and $442 \mathrm{~B}-9-3,110 \mathrm{~cm}$ & 1 & Aphyric, massive basalt \\
$442-2$ & $442 \mathrm{~B}-13-3,25 \mathrm{~cm}$ & 2 & Aphyric, pillow basalt \\
$442-3$ & $442 \mathrm{~B}-17-1,80 \mathrm{~cm}$ & 2 & Aphyric, pillow basalt \\
$442-4$ & $442 \mathrm{~B}-20-1,65 \mathrm{~cm}$ (base) & 2 & Aphyric, pillow basalt \\
$443-1$ & $443-52-1$, above $90 \mathrm{~cm}$ & 2 & Sparsely Pl and Ol phyric basalt \\
$443-2$ & $443-54-8,25 \mathrm{~cm}$ & 2 & Sparsely Pl and Ol phyric basalt \\
$443-3$ & $443-58-4,130 \mathrm{~cm}$ & $3 \mathrm{a}-3 \mathrm{~d}$ & Aphyric, pillow basalt \\
$443-4$ & $443-63-8,110 \mathrm{~cm}$ & $3 \mathrm{e}-5 \mathrm{e}$ & Aphyric to Pl and Ol phyric basalt \\
$443-5$ & $443-64-4,35 \mathrm{~cm}$ (base) & 6 & Sparsely Ol and Pl phyric basalt \\
$444-1$ & $444 \mathrm{~A}-20-4,115 \mathrm{~cm}$ & 1 & Aphyric, kaersutite-bearing basalt \\
$444-2$ & $444 \mathrm{~A}-27-5,100 \mathrm{~cm}$ (base) & 2 & Pl phyric basalt \\
$446-1$ & $446-42, \mathrm{CC}$ and $446 \mathrm{~A}-2-3,21 \mathrm{~cm}$ & 1 & Aphyric basalt \\
$446-2$ & $446-45-1,10 \mathrm{~cm}$ and $446 \mathrm{~A}-6-2,75 \mathrm{~cm}$ & 2 & Aphyric to sparsely Pl and Cpx phyric basalt \\
$446-3$ & $446-46-1,100 \mathrm{~cm}$ (base) and $446 \mathrm{~A}-9-3,150 \mathrm{~cm}$ & 3 & Sparsely Pl and Cpx phyric basalt \\
$446-4$ & $446 \mathrm{~A}-11-3,55 \mathrm{~cm}$ & $4 \mathrm{a}$ & Coarse-grained, kaersutite-bearing basalt \\
$446-5$ & $446 \mathrm{~A}-13-2,55 \mathrm{~cm}$ & $4 \mathrm{~b}-5$ & Variably Ol phyric, kaersutite-bearing basalt \\
$446-6$ & $446 \mathrm{~A}-16-2,105 \mathrm{~cm}$ & $6 \mathrm{a}$ & Aphyric basalt \\
$446-7 \mathrm{a}$ & $446 \mathrm{~A}-18-5,50 \mathrm{~cm} ?$ & $6 \mathrm{c}-6 \mathrm{~d} ?$ & Aphyric basalt \\
$446-7 \mathrm{~b}$ & $446 \mathrm{~A}-19-4,20 \mathrm{~cm}$ ? & $6 \mathrm{~d}-6 \mathrm{e}$ & Aphyric basalt \\
$446-8$ & $446 \mathrm{~A}-21-6,60 \mathrm{~cm}$ & $6 \mathrm{f}$ & Sub-aphyric basalt with rare Pl phenocrysts \\
$446-9$ & $446 \mathrm{~A}-22-1,35 \mathrm{~cm}$ & $6 \mathrm{~g}$ & Aphyric basalt \\
$446-10$ & $446 \mathrm{~A}-22-4,105 \mathrm{~cm}$ & $6 \mathrm{~h}$ & Aphyric basalt \\
$446-11$ & $446 \mathrm{~A}-23-6,140 \mathrm{~cm}$ & $7 \mathrm{a}-7 \mathrm{~b}$ & Sparsely Pl and Cpx phyric \\
$446-12$ & $446 \mathrm{~A}-24-1,65 \mathrm{~cm}$ & $8 \mathrm{a}$ & Sparsely Pl and Cpx phyric \\
$446-13$ & $446 \mathrm{~A}-25-3,85 \mathrm{~cm}$ & $8 \mathrm{~b}$ & Sub-aphyric basalt with rare Pl phenocrysts \\
$446-14$ & $446 \mathrm{~A}-26-3,55 \mathrm{~cm}$ & 9 & Aphyric basalt \\
$446-15$ & $446 \mathrm{~A}-27-2,140 \mathrm{~cm}$ & & \\
\hline
\end{tabular}

${ }^{\mathrm{a}}$ See site chapters, this volume; lithologic units $443-1,446-6 \mathrm{~b}$, and $446-8 \mathrm{c}$ were not sampled.

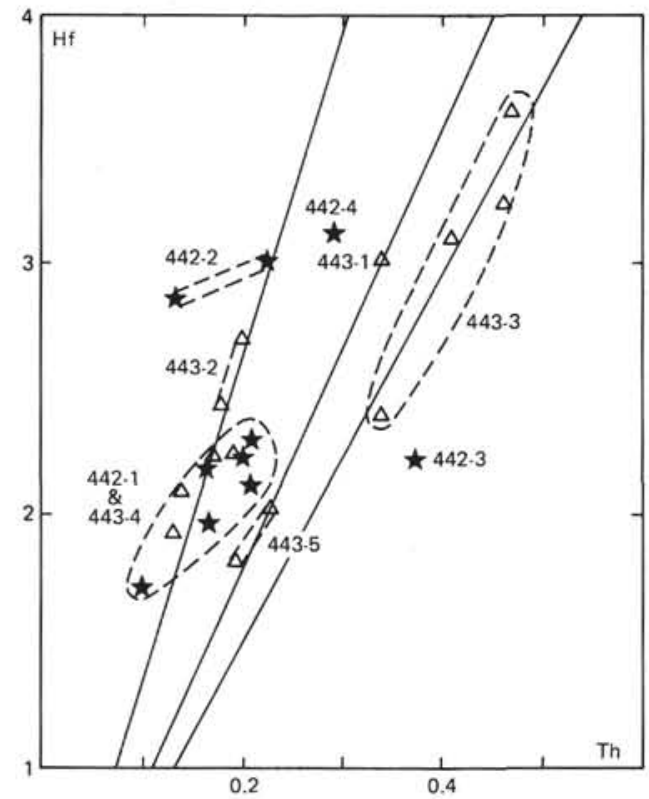

Figure 5. Hf versus Th for samples from Sites 442 and 443. Geochemical units are distinguished. Symbols are those used in Figure 2. Lines represent constant $\mathrm{Th} / \mathrm{Hf}$ ratios. Concentrations are in ppm.

some of the T-type MORB of the Reykjanes Ridge with their higher $\mathrm{Nb} / \mathrm{La}$ and $\mathrm{Th} / \mathrm{Hf}$ ratios (Wood et al., 1979).
The alkali-basalt unit $444-1$ is similar to the low-Fe and -Ti alkali basalts (E-type MORB) drilled at $45^{\circ} \mathrm{N}$ on the Mid-Atlantic Ridge, although the latter have higher $\mathrm{CaO}$ (>10 wt. \%), lower $\mathrm{K}_{2} \mathrm{O}(<1$ wt. $\%$ ), and slightly higher Th relative to the other HYG elements (Wood et al., 1979). The quartz-normative group of Ti-rich basalts from Site 446 have HYG-element abundances similar to those of some ferrobasalts (E-type MORB) from Iceland, including higher $\mathrm{Nb} / \mathrm{La}$ (and, we assume, $\mathrm{Ta} / \mathrm{La}$ ) than N-type MORB (Wood et al., in press). The alkalic group from Site 446, with higher values of $\mathrm{K}, \mathrm{Sr}$, $\mathrm{Ba}$, etc., than the quartz-normative group, has similarities in major- and trace-element abundances with some basalts from the Azores (Joron et al., in prep.). The fields of the different MORB types and selected samples from Iceland and the Azores are included in Figure 6.

In addition to the determination of $\mathrm{La}, \mathrm{Eu}$, and $\mathrm{Tb}$ by INAA and $\mathrm{Ce}$ and $\mathrm{Y}$ by $\mathrm{XRF}, \mathrm{Sm}, \mathrm{Yb}$, and $\mathrm{Lu}$ have also been determined by INAA on eight samples from Holes 443 and 446. A more comprehensive study of REE in the Leg 58 cores is presently being undertaken, but these data have enabled us to construct REE patterns for at least some of the basalt types. These are plotted, normalized to the average abundances of 10 ordinary chondrites (Nakamura, 1974), together with some patterns for N-, T-, and E-type MORB from the North Atlantic Ocean (Figure 8). Comparisons among them confirm the similarities outlined above and indicate that unit 444-1 and basalts from Site 446 fall within the range of E-type MORB erupted in the Atlan- 


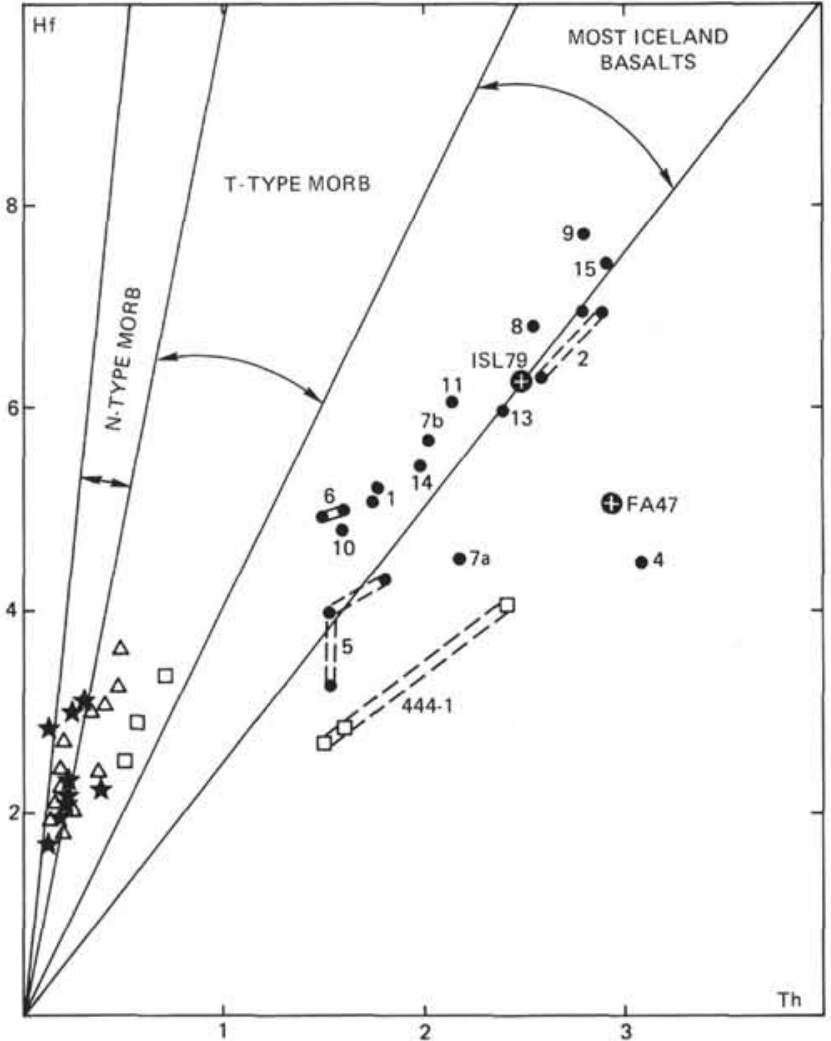

Figure 6. Hf versus Th for samples from all Leg 58 sites, together with Iceland basalt ISL79 and Azores basalt FA47 (cf. Table 1). The range of $\mathrm{Th} / \mathrm{Hf}$ ratios shown by the different MORB types have been included. Symbols and numbers are used in the same sense as in Figure 2. Concentrations are in ppm.

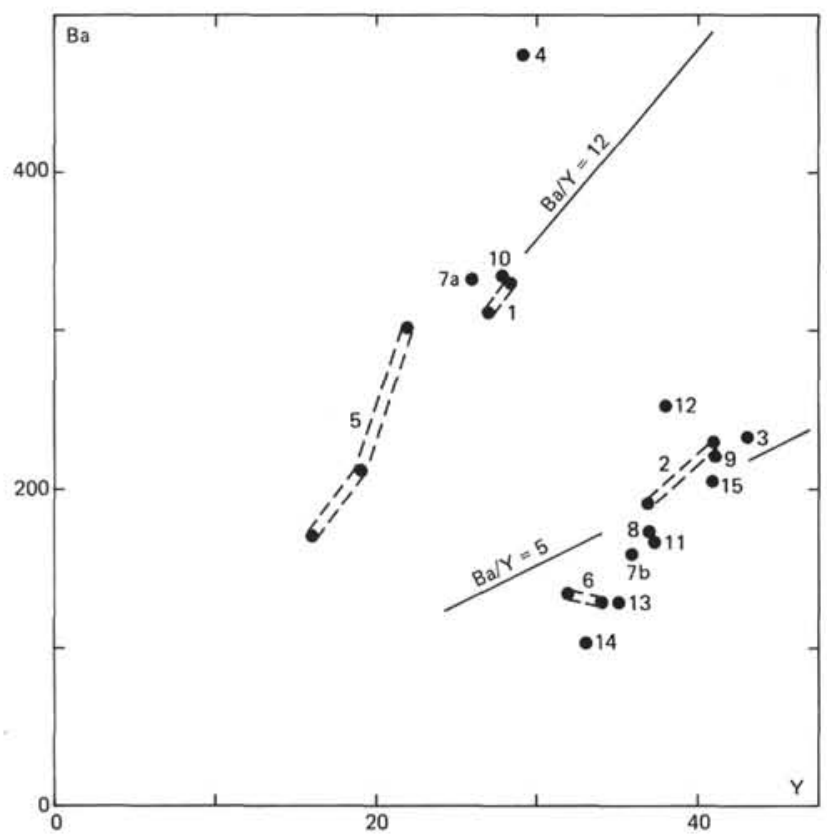

Figure 7. Ba versus $Y$ for samples from Site 446, with the geochemical units distinguished. Concentrations are in ppm. tic Ocean. The occurrence of these basalt types as sills intruded into the sediments above basaltic basement is indicative of off-axis volcanism, which is consistent with the nature of eruption of much of the E-type MORB found in the major ocean basins.

\section{THE LAVA SERIES OF JAPAN}

The Japanese Islands form island-arc systems belonging to the circum-Pacific orogenic zone (Figure 1). They are underlain by slivers of continental crust that have been separated from the Asian continental margin by backarc extension in the Japan Sea. The well-documented spatial zonation of magma series across the Japanese arcs (Tilley, 1950; Kuno, 1950) has formed the basis of generalized schemes for the spatial compositional variation of island-arc magmas, i.e., the progressive change from tholeiitic to calc-alkalic to alkalic with distance from the trench (Kuno, 1966; Jakes and White, 1972) and the correlation between alkalinity of the magma types and depth to the Benioff zone - the so called K- $h$ relationship (Dickinson and Hatherton, 1967). Although such generalized schemes are oversimplifications of the spatial variations in island arcs throughout the world (Arculus and Johnson, 1978) the tectonic controls on the nature of magmatism are clearly important in Japan.

Three main magma series have been distinguished in Japan (Kuno, 1959; Katsui, 1961), and their approximate spatial distributions are shown in Figure 9. The tholeiitic (or pigeonitic) series (1) with its trend towards enrichment of $\mathrm{Fe}$ relative to alkalis is found on the Pacific side of the arc; the high-alumina-basalt series (2) and associated calc-alkalic (or hypersthenic) fractionation trend occur in a central zone parallel to the elongation of Japan; the alkali-basalt series (3), with its fractionation trend towards enrichment of alkalis relative to $\mathrm{Fe}$, occurs on the Japan Sea side of the arc. Representative major-element analyses from each of the three series are shown in Tables 4 to 6 , and trace-element analyses are presented in Table 7.

Superimposed on the tholeiitic and alkalic zones are additional calc-alkalic series, i.e., lavas with groundmass hypersthene (Kuno, 1960; Yagi et al., 1963; Aoki and Oji, 1966). There is a similar gradation in the chemistry of the calc-alkalic series of the three zones, i.e., a progressive increase in the alkalic-element contents for lavas with the same $\mathrm{SiO}_{2}$ concentrations from the tholeiitic to alkalic zone (Masuda et al., 1975).

The lavas of the calc-alkalic series associated with the alkalic and tholeiitic zones may be the result of contamination of the main magma type of the zone by continental crust (Aoki and Oji, 1966); the ubiquitous xenocrysts in these lavas support this conclusion.

Lateral chemical variations are found in the contents of $\mathrm{Ba}, \mathrm{Th}$, and the light REE (Figure 10) in the basaltic and associated calc-alkalic series of the three zones (Jakes and Gill, 1970; Masuda et al., 1975). The lavas of the tholeiitic zone have flat or slightly light-REEdepleted patterns, with low absolute abundances of all the REE and large variations in the La contents relative to the other light REE (Masuda, 1968). The lavas of the 

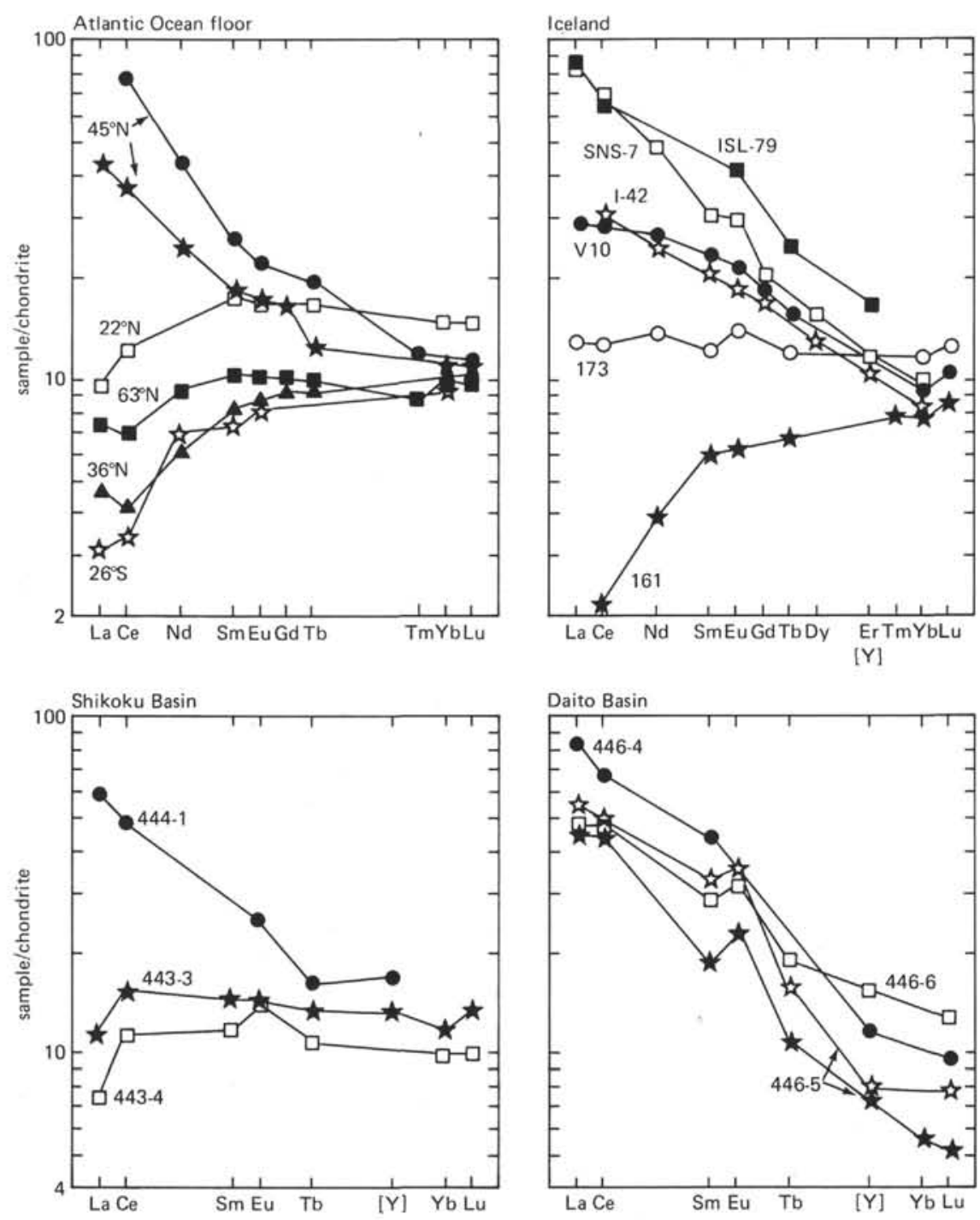

Figure 8. Chondrite-normalized REE diagrams for seven Leg 58 basalts, together with data for basalts from the Atlantic Ocean floor and Iceland. Data for the Atlantic Ocean comes from $36^{\circ} \mathrm{N}, 45^{\circ} \mathrm{N}$, and $63^{\circ} \mathrm{N}$ (Wood et al., 1979a), $22^{\circ} \mathrm{N}$ (Rhodes et al., 1978) and $26^{\circ} \mathrm{S}$ (Frey et al., 1974). Data for Iceland comes from O'Nions et al. (1973, 1976), and Wood et al. (1979b).

high-alumina-basalt zone have high absolute abundances of the REE and are enriched in the light REE; those of the alkalic zone are strongly enriched in the light REE.

Kuno $(1960,1968)$ discriminated among the lavas from the three zones on the basis of major elements, using alkali-silica and AFM diagrams. The Japanese suites and Leg 58 samples used in this study have been plotted on these diagrams together with Kuno's boundaries (Figures 11, 12). Tholeiitic and calc-alkalic series associated with island arcs have been distinguished from $\mathrm{N}$-type MORB by their lower $\mathrm{Na}_{2} \mathrm{O} / \mathrm{K}_{2} \mathrm{O}$ and $\mathrm{Ni} / \mathrm{Co}$ ratios and $\mathrm{Cr}$ and $\mathrm{Ni}$ contents, but higher alkalielement, $\mathrm{Th}$, and radiogenic $\mathrm{Sr}$ and $\mathrm{Pb}$ contents (Taylor et al., 1969; Jakes and Gill, 1970; Sun, 1979). Using some of these discriminants and the variations shown in
Figures 11 and 12 , it becomes clear that none of the tholeiitic lavas from the Shikoku Basin are in any way transitional between N-type MORB and island-arc magma series.

Comparison of the alkali basalts of Sites 444 and 446 with the alkalic series of Japan reveals many similarities: predictably, all are strongly enriched in the light REE and have high abundances of the alkali elements. Nevertheless, the Site 446 alkali basalts can be distinguished from the Oki-Dogo alkali basalts by their higher $\mathrm{TiO}_{2}$ and $\mathrm{CaO}$ contents, and the Site 444 alkali basalts can be distinguished by their lower $\mathrm{FeO}$ contents (Figure 11). In HYG-element contents, the Oki-Dogo alkalic series can be distinguished from both the Leg 58 alkali basalts by their higher contents of $\mathrm{Cs}, \mathrm{Rb}, \mathrm{Ba}$, and $\mathrm{Th}$ relative to light REE and the less-HYG elements, i.e., 


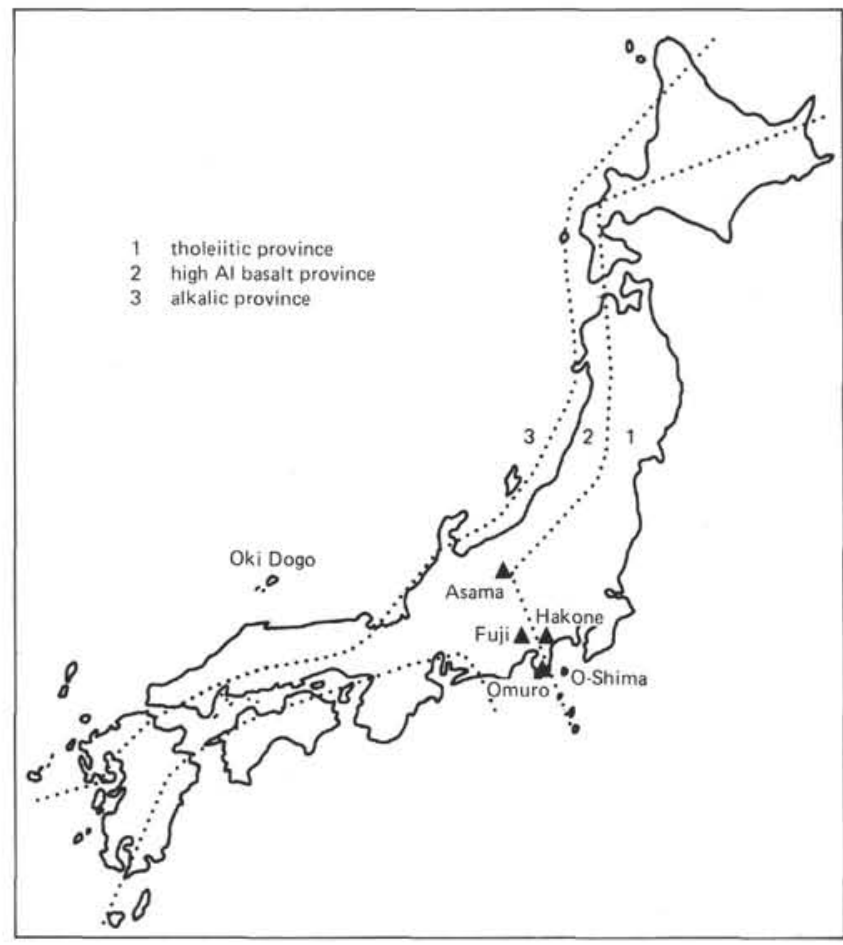

Figure 9. Sketch map of Japan showing the approximate boundaries between the basalt provinces (dotted lines), and also the locations of the samples used in this study. The boundaries are from Kuno (1959) with minor modifications by Aoki and Oji (1966) and Masuda et al. (1975). higher $\mathrm{Ba} / \mathrm{La}$ and $\mathrm{Th} / \mathrm{Hf}$ ratios. Figure 11 shows that two fractionation trends have been distinguished in the Oki-Dogo series, a high-Fe series of alkali basalt $\rightarrow$ mugearite $\rightarrow$ trachyte $\rightarrow$ quartz rhyolite; and a low-Fe series of alkali basalt $\rightarrow$ trachyandesite $\rightarrow$ trachyte $\rightarrow$ rhyolite (Uchimizu, 1966). A Pb-isotope study of the Oki-Dogo series (Kurasawa, 1968) has shown that this may be a result of variable crustal contamination. It is therefore uncertain whether the observed major- and trace-element compositions of the lavas are representative of the parental alkalic magma. The compositional differences between the Oki-Dogo basalts and Leg 58 unit 444-1 (the alkali basalt nearest to it in composition) may therefore be the result of contamination.

Figures 13,14, and 15 show plots of Th versus Hf, Th versus $\mathrm{La}$, and $\mathrm{Ba}$ versus $\mathrm{La}$, respectively, for the Leg 58 Japanese samples. The $\mathrm{Th} / \mathrm{Hf}$ ratios in the arc tholeiites are significantly higher than for $\mathrm{N}$ - and T-type MORB, and they increase progressively for the high-aluminabasalt and alkali-basalt series. Th and Hf have very different $D$ values; $D_{\mathrm{Th}}$ probably is an order of magnitude lower than $D_{\mathrm{Hf}}$ for most upper-mantle systems $(\mathrm{Ol}+$ $\mathrm{Opx}+\mathrm{Cpx} \pm \mathrm{Gt} \pm \mathrm{Pl}$ ), so the $\mathrm{Th} / \mathrm{Hf}$ ratio can be significantly modified by partial-melting processes (but not by fractional-crystallization processes, because both $D_{\mathrm{Th}}$ and $D_{\mathrm{Hf}}$ are significantly less than 1). The Th/Hf ratios of basaltic lavas cannot therefore be interpreted as representative of the mantle sources from which they are derived. On the other hand, the differences among $D_{\mathrm{Th}}, D_{\mathrm{Ba}}$, and $D_{\mathrm{La}}$ are not as great $\left(D_{\mathrm{La}}\right.$ is slightly higher than the other two), so the $\mathrm{Th} / \mathrm{La}$ and $\mathrm{Ba} / \mathrm{La}$ ratios of basaltic lavas are not dependent on partial-melting pro-

TABLE 4

Major-Element Analyses of Selected Alkalic Lava Series of Dogo, Oki Islands ${ }^{\mathrm{a}}$

\begin{tabular}{|c|c|c|c|c|c|c|c|c|c|c|}
\hline \multirow[b]{2}{*}{ Component } & 1 & 2 & 3 & 4 & 5 & 6 & 7 & 8 & 9 & 10 \\
\hline & \multicolumn{10}{|c|}{ (wt. \%) } \\
\hline $\mathrm{SiO}_{2}$ & 46.88 & 48.03 & 50.54 & 52.85 & 60.63 & 62.7 .5 & 61.57 & 65.08 & 65.75 & 67.45 \\
\hline $\mathrm{TiO}_{2}$ & 1.94 & 2.53 & 2.64 & 2.97 & 1.02 & 1.12 & 0.37 & 0.73 & 0.73 & 0.27 \\
\hline $\mathrm{Al}_{2} \mathrm{O}_{3}$ & 15.20 & 16.25 & 14.44 & 16.68 & 15.05 & 15.49 & 17.95 & 15.05 & 15.29 & 14.01 \\
\hline $\mathrm{Fe}_{2} \mathrm{O}_{3}$ & 4.48 & 3.10 & 3.58 & 1.43 & 3.44 & 1.82 & 3.19 & 2.57 & 3.04 & 0.82 \\
\hline $\mathrm{FeO}$ & 6.09 & 7.04 & 8.24 & 8.21 & 2.94 & 3.12 & 2.39 & 2.06 & 0.86 & 1.92 \\
\hline $\mathrm{MnO}$ & 0.15 & 0.16 & 0.21 & 0.20 & 0.10 & 0.09 & 0.15 & 0.14 & 0.10 & 0.09 \\
\hline $\mathrm{MgO}$ & 10.11 & 6.12 & 3.08 & 2.82 & 2.27 & 1.45 & 0.07 & 0.45 & 0.81 & 0.12 \\
\hline $\mathrm{CaO}$ & 9.62 & 6.88 & 6.98 & 6.81 & 4.56 & 3.50 & 0.87 & 1.62 & 1.66 & 0.81 \\
\hline $\mathrm{Na}_{2} \mathrm{O}$ & 3.04 & 4.63 & 3.75 & 3.72 & 3.60 & 3.46 & 6.25 & 4.35 & 4.32 & 3.47 \\
\hline $\mathrm{K}_{2} \mathrm{O}$ & 1.42 & 1.48 & 2.91 & 3.43 & 3.48 & 5.42 & 5.35 & 5.39 & 5.75 & 5.87 \\
\hline $\mathrm{P}_{2} \mathrm{O}_{5}$ & 0.36 & 0.12 & 0.34 & 0.14 & 0.52 & 0.30 & 0.06 & 0.18 & 0.18 & 0.05 \\
\hline $\mathrm{H}_{2} \mathrm{O}+$ & 0.49 & 1.61 & 2.38 & 0.75 & 0.86 & 1.17 & 1.20 & 0.98 & 0.75 & 4.81 \\
\hline $\mathrm{H}_{2} \mathrm{O}-$ & 0.55 & 2.35 & 1.15 & 0.35 & 1.25 & 0.15 & 0.75 & 1.15 & 0.50 & 0.30 \\
\hline Total & 100.33 & 100.30 & 100.24 & 100.36 & 99.72 & 99.84 & 100.17 & 99.75 & 99.74 & 99.69 \\
\hline Total Fe & 10.12 & 9.83 & 11.46 & 9.50 & 6.04 & 4.76 & 5.26 & 4.37 & 3.60 & 2.66 \\
\hline $\mathrm{Mg} /(\mathrm{Mg}+\mathrm{F}$ & 0.668 & 0.557 & 0.352 & 0.374 & 0.431 & 0.381 & 0.026 & 0.172 & 0.312 & 0.083 \\
\hline
\end{tabular}

a Analyses from Uchimizu (1966); 1, olivine trachybasalt (6082003); 2, groundmass of kaersutite trachybasalt (60525);

3 , plagioclase-bearing mugearite $(60520) ; 4$, aphyric mugearite $(6072805) ; 5$, hypersthene-augite trachyandesite (6372501); 6, hypersthene-augite trachyandesite (6372508); 7, aegirine trachyte (59332); 8, ferroaugite trachyte (6351301); 9, hypersthene-augite trachyte $(6351401) ; 10$, rhyolite pumice (6282204). 
TABLE 5

Major-Element Analyses of Selected Tholeiitic Lava Series from Honshu and the Iwo Jima Ridge ${ }^{a}$

\begin{tabular}{|c|c|c|c|c|c|c|c|c|c|c|c|}
\hline \multirow[b]{3}{*}{ Component } & \multicolumn{3}{|c|}{ Hakone } & \multicolumn{4}{|c|}{ O-shima } & \multicolumn{4}{|c|}{ Hachijo-jima } \\
\hline & 11 & 12 & 13 & 14 & 15 & 16 & 17 & 18 & 19 & 20 & 21 \\
\hline & & & & & & (wt.\%) & & & & & \\
\hline $\mathrm{SiO}_{2}$ & 48.73 & 58.13 & 63.41 & 51.02 & 51.25 & 52.59 & 52.52 & 52.10 & 55.84 & 51.79 & 54.67 \\
\hline $\mathrm{TiO}_{2}$ & 0.63 & 1.10 & 0.81 & 0.79 & 0.81 & 1.41 & 0.83 & 0.79 & 1.28 & 1.40 & 1.64 \\
\hline $\mathrm{Al}_{2} \mathrm{O}_{3}$ & 16.53 & 15.23 & 16.30 & 14.39 & 14.73 & 15.05 & 15.14 & 15.70 & 14.94 & 16.08 & 14.47 \\
\hline $\mathrm{Fe}_{2} \mathrm{O}_{3}$ & 3.37 & 4.43 & 2.83 & 3.17 & 3.82 & 3.28 & 3.79 & 2.96 & 2.42 & 1.52 & 1.86 \\
\hline $\mathrm{FeO}$ & 8.44 & 5.68 & 3.75 & 9.98 & 10.22 & 10.61 & 9.62 & 7.91 & 9.45 & 11.28 & 12.30 \\
\hline $\mathrm{MnO}$ & 0.29 & 0.18 & 0.15 & 0.23 & 0.28 & 0.16 & 0.30 & 0.23 & 0.22 & 0.20 & 0.32 \\
\hline $\mathrm{MgO}$ & 8.24 & 3.02 & 1.63 & 7.48 & 5.47 & 4.67 & 5.11 & 6.02 & 3.55 & 4.41 & 3.03 \\
\hline $\mathrm{CaO}$ & 12.25 & 7.26 & 5.96 & 11.35 & 11.73 & 9.99 & 10.10 & 11.61 & 8.05 & 9.98 & 8.03 \\
\hline $\mathrm{Na}_{2} \mathrm{O}$ & 1.21 & 3.30 & 4.03 & 1.29 & 1.85 & 1.65 & 2.03 & 1.77 & 2.68 & 2.00 & 2.59 \\
\hline $\mathrm{K}_{2} 2 \mathrm{O}$ & 0.23 & 0.76 & 0.75 & 0.15 & 0.26 & 0.40 & 0.43 & 0.35 & 0.47 & 0.35 & 0.50 \\
\hline $\mathrm{P}_{2} \mathrm{O}_{5}$ & 0.10 & 0.20 & 0.18 & 0.07 & 0.13 & 0.20 & 0.15 & 0.07 & 0.12 & 0.09 & 0.16 \\
\hline $\mathrm{H}_{2} \mathrm{O}^{+}$ & - & 0.43 & 0.36 & 0.32 & 0.11 & - & - & 0.19 & 0.89 & 0.51 & 0.45 \\
\hline $\mathrm{H}_{2} \mathrm{O}-$ & - & 0.15 & 0.15 & 0.25 & 0.02 & - & - & 0.12 & 0.16 & 0.08 & 0.09 \\
\hline Total & 100.02 & 99.87 & 100.31 & 100.49 & 100.84 & 100.01 & 100.03 & 99.82 & 100.07 & 99.69 & 100.11 \\
\hline Total F & 11.47 & 9.67 & 6.30 & 12.83 & 13.66 & 13.56 & 13.03 & 10.57 & 11.63 & 12.65 & 13.97 \\
\hline $\mathrm{Mg} /\left(\mathrm{Mg}+\mathrm{Fe}^{2+}\right)$ & 0.592 & 0.386 & 0.343 & 0.540 & 0.447 & 0.410 & 0.442 & 0.535 & 0.381 & 0.413 & 0.304 \\
\hline
\end{tabular}

analyses from indicated sources: 11, calculated parental magma of the "pigeonitic series" of the Izu and Hakone Province (Kuno, 1954); 12, aphyric andesite (3), old Somma, Hakone Volcano (Fujimaki, 1975); 13, augite-hypersthene andesite (7), old Somma, Hakone Volcano (Fujimaki, 1975); 14, aphyric basalt (HK36092301-b), Okata, O-shima, Izu Islands (Kuno, 1965); 15, aphyric basalt Okata, Oshima, Izu Islands (Kuno, 1960, analysis 2, table 1);16, average of 6 post-caldera lavas, O-shima (Kuno, 1954); 17, average of 3 pre-caldera lavas, O-shima (Kuno, 1954); 18, sub-aphyric augite-olivine basalt (NI5 2092601), pre-caldera, Higashi-yama volcano, Hachijo-jima Island (Isshiki, 1963); 19, aphyric andesite (NI54072007), pre-caldera, Higashi-yama volcano (Isshiki, 1963); 20, aphyric basalt (NI54050703) Nishi-yama volcano, Hachijo-jima Island (Isshiki, 1963); 21, aphyric basalt (83), Nishi-yama volcano, Hachijo-jima (Tsuya, 1937).

TABLE 6

Major-Element Analyses of Selected High-Alumina Basalt and Calc-Alkalic Lava Series of the Huzi and Tyokai Volcanic Zones ${ }^{\mathrm{a}}$

\begin{tabular}{|c|c|c|c|c|c|c|c|c|c|c|c|}
\hline \multirow{3}{*}{ Component } & \multicolumn{8}{|c|}{ Huzi Zone } & \multicolumn{3}{|c|}{ Tyokai Zone } \\
\hline & 22 & 23 & 24 & 25 & 26 & 27 & 28 & 29 & $30^{\mathrm{b}}$ & $31^{\mathrm{b}}$ & $32 \mathrm{~b}$ \\
\hline & \multicolumn{11}{|c|}{ (wt. \%) } \\
\hline $\mathrm{SiO}_{2}$ & 48.76 & 54.99 & 49.51 & 50.99 & 51.09 & 58.02 & 56.03 & 55.62 & 50.36 & 53.56 & 64.73 \\
\hline $\mathrm{TiO}_{2}$ & 1.39 & 2.02 & 0.64 & 1.06 & 1.38 & 0.72 & 0.74 & 0.86 & 1.11 & 0.81 & 0.63 \\
\hline $\mathrm{Al}_{2} \mathrm{O}_{3}$ & 18.53 & 13.86 & 18.19 & 17.14 & 17.62 & 16.94 & 17.90 & 16.91 & 19.08 & 18.52 & 15.98 \\
\hline $\mathrm{Fe}_{2} \mathrm{O}_{3}$ & 4.12 & 3.93 & 2.89 & 4.53 & 2.64 & 2.12 & 1.69 & 2.02 & 3.59 & 3.01 & 2.85 \\
\hline $\mathrm{FeO}$ & 8.07 & 8.57 & 7.66 & 8.06 & 8.42 & 5.08 & 6.16 & 6.24 & 5.67 & 5.21 & 2.42 \\
\hline $\mathrm{MnO}$ & 0.19 & 0.24 & 0.28 & 0.23 & 0.21 & 0.17 & 0.11 & 0.14 & 0.15 & 0.13 & 0.15 \\
\hline $\mathrm{MgO}$ & 5.47 & 2.89 & 7.07 & 5.11 & 5.09 & 4.31 & 4.13 & 5.87 & 5.28 & 4.80 & 1.95 \\
\hline $\mathrm{CaO}$ & 10.01 & 6.48 & 9.83 & 9.78 & 9.68 & 6.86 & 8.40 & 8.63 & 9.85 & 7.88 & 4.67 \\
\hline $\mathrm{Na}_{2} \mathrm{O}$ & 2.69 & 3.28 & 2.49 & 2.32 & 2.80 & 3.40 & 2.83 & 2.98 & 2.59 & 3.47 & 3.76 \\
\hline $\mathrm{K}_{2} \mathrm{O}$ & 0.72 & 2.09 & 0.48 & 0.46 & 0.76 & 1.05 & 0.83 & 0.72 & 1.10 & 1.44 & 1.64 \\
\hline $\mathrm{P}_{2} \mathrm{O}_{5}$ & 0.28 & 0.81 & 0.17 & 0.17 & 0.26 & 0.19 & 0.22 & 0.24 & 0.15 & 0.21 & 0.13 \\
\hline $\mathrm{H}_{2} \mathrm{O}+$ & 0.40 & 1.08 & 0.45 & 0.64 & 0.28 & 0.80 & 0.60 & 0.35 & 0.53 & 0.44 & 0.80 \\
\hline $\mathrm{H}_{2} \mathrm{O}-$ & - & - & 0.27 & 0.17 & 0.06 & 0.24 & 0.27 & 0.05 & 0.54 & 0.52 & 0.31 \\
\hline Total & 100.63 & 100.24 & 99.93 & 100.66 & 100.29 & 99.90 & 100.11 & 100.63 & 100.00 & 100.00 & 100.00 \\
\hline Total $\mathrm{Fe}$ as $\mathrm{FeO}$ & 11.78 & 12.11 & 10.26 & 12.14 & 10.80 & 6.99 & 7.68 & 8.06 & 8.90 & 7.92 & 4.98 \\
\hline $\mathrm{Mg} /\left(\mathrm{Mg}+\mathrm{Fe}^{2+}\right)$ & 0.484 & 0.325 & 0.582 & 0.459 & 0.487 & 0.554 & 0.520 & 0.595 & 0.545 & 0.550 & 0.441 \\
\hline
\end{tabular}

\footnotetext{
${ }^{a}$ Analyses from indicated sources: 22, high-alumina olivine basalt (HK55061903a), pre-historic Mishima flow, Fuji Volcano (Kuno, 1965); 23, segregation vein in lava 22 (Kuno, 1965); 24, olivine basalt, Maruno-yama lava, Amagi (Tsuya, 1937); 25, olivine basalt, Niijima (Kuno, 1960); 26, augite-bearing olivine basalt, 1707 eruption of Huzi (Tsuya, 1937); 27, olivine andesite, Komuro-yama volcano, Izu Peninsula (Kuno, 1954, table 2, analysis 9); 28, olivine andesite, Komuro-yama volcano, Izu Peninsula (Kuno, 1954, table 2, analysis 6); 29, olivine andesite (HK62090502), Omuro-yama volcano, Izu Peninsula (Kuno, 1965); 30, parental high-alumina basalt, Tyokai zone (Yagi et al., 1963); 31, average high-alumina basalt, Tyokai zone (Yagi et al., 1963); 32, average dacite, Tyokai zone (Yagi et al., 1963).

Recalculated to total $100 \%$.
} 
TABLE 7

Trace-Element Analyses of 36 Japanese Lavas

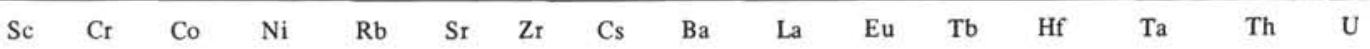

Sample No., Rock Type

(ppm)

\begin{tabular}{|c|c|c|c|c|c|c|c|c|c|c|c|c|c|c|c|c|}
\hline \multicolumn{17}{|l|}{ Alkalic series } \\
\hline \multicolumn{17}{|l|}{ Oki-Dogo } \\
\hline MU6082003 - trachybasalt & 24.3 & 507 & 48.9 & 264 & 48 & 793 & 173 & 0.56 & 499 & - & 1.85 & 0.67 & 3.85 & 2.39 & 3.74 & - \\
\hline OK 1 - trachybasalt & 20.2 & 187 & 43.2 & 157 & 47 & - & 198 & 0.47 & 686 & 31.5 & 2.50 & 0.83 & 4.43 & 2.85 & 3.32 & 0.65 \\
\hline OK3 - trachybasalt & 27.0 & 535 & 54.3 & 298 & 46 & - & 163 & 0.42 & 637 & 23.5 & 2.00 & 0.61 & 3.56 & 2.32 & 3.17 & 0.53 \\
\hline OK4 - trachy basalt & 25.2 & 498 & 53.6 & 281 & 47 & - & 161 & 0.66 & 518 & 24.7 & 1.81 & 0.62 & 3.53 & 2.32 & 3.48 & 0.55 \\
\hline OK5 - trachybasalt & 25.4 & 459 & 50.3 & 258 & 50 & - & 166 & 0.53 & 530 & 25.4 & 1.89 & 0.65 & 3.66 & 2.33 & 3.59 & 0.66 \\
\hline MU60520 - mugearite & 17.7 & 35 & 15.2 & 0 & 74 & 521 & 416 & 0.28 & 1505 & - & 3.88 & 1.20 & 9.35 & 3.56 & 8.6 & - \\
\hline OK 7 - mugearite & 21.3 & 54 & 18.0 & 8.9 & 66 & - & 395 & 0.59 & 2841 & 58 & 4.9 & 1.17 & 7.9 & 3.52 & 6.76 & 1.20 \\
\hline OK9-mugearite & 18.0 & 37 & 15.2 & 8.5 & 78 & - & 419 & 0.44 & 1545 & 62 & 4.2 & 1.16 & 9.2 & 3.58 & 8.8 & 1.55 \\
\hline MU6372501 - trachyandesite & 14.1 & 28 & 11.8 & 2.6 & 84 & 445 & 205 & 1.65 & 445 & - & 1.46 & 0.66 & 5.7 & 0.68 & 7.13 & - \\
\hline MU59332 - aegirine trachyte & 1.0 & 0 & 0.8 & 2.3 & 292 & - & 1014 & 1.05 & 103 & - & 0.66 & 1.82 & 26.8 & 17.9 & 34.3 & - \\
\hline MU6351301 - trachyte & 7.7 & 20 & 1.2 & 2.4 & 122 & 110 & 649 & 0.52 & 1385 & - & 2.66 & 1.02 & 14.8 & 3.80 & 13.3 & - \\
\hline OK12 - trachyte & 6.5 & 26 & 4.5 & 5.1 & 137 & - & 545 & 1.20 & 1268 & 56 & 1.63 & 0.76 & 13.3 & 3.01 & 14.9 & 2.46 \\
\hline MU6351401 - trachyte & 6.6 & 16 & 4.9 & 2.7 & 148 & 195 & 530 & 1.32 & 1178 & - & 1.65 & 0.81 & 13.2 & 3.02 & 15.7 & - \\
\hline OK11 - rhyolite & 4.5 & 20 & 2.3 & 2.3 & 160 & - & 558 & 1.51 & 1053 & 59 & 1.25 & 0.76 & 13.5 & 2.93 & 17.3 & 2.90 \\
\hline MU6282204 - rhyolite & 6.3 & 0 & 0.4 & 0 & 168 & - & 544 & 1.37 & 25 & - & 0.18 & 1.18 & 16.5 & 4.41 & 20.5 & - \\
\hline \multicolumn{17}{|l|}{ Tholeiitic series } \\
\hline \multicolumn{17}{|l|}{ O-shima } \\
\hline OS2 basalt & 39.5 & 54 & 35.8 & 13.3 & - & - & $<20$ & 0.06 & 61 & 0.87 & 0.37 & 0.20 & 0.51 & 0.012 & 0.12 & 0.03 \\
\hline $56 / 020 \mathrm{~b}$ & 50.4 & 98 & 36.1 & 14.2 & - & 174 & $<45$ & 0.28 & 79 & 0.93 & 0.39 & 0.29 & 0.81 & 0.017 & 0.05 & - \\
\hline 10376 basalt & 49.4 & 74 & 12.2 & 11.0 & 4.5 & 186 & 74 & 0.75 & 203 & 1.9 & 0.86 & 0.53 & 1.54 & 0.035 & 0.31 & 0.08 \\
\hline OS3 basalt & 51.0 & 72 & 38.4 & 11 & 4.4 & 186 & 74 & 0.76 & 175 & 2.0 & 0.82 & 0.52 & 1.32 & 0.03 & 0.26 & 0.12 \\
\hline OS5 basalt & 52.6 & 69 & 40.4 & 25 & 5.3 & - & 87 & 0.83 & 220 & 2.5 & 0.80 & 0.54 & 1.57 & 0.040 & 0.32 & 0.15 \\
\hline 10378 basalt & 54.4 & 72 & 42.1 & 14.8 & 6.7 & - & 87 & 0.81 & 210 & 2.6 & 0.80 & 0.54 & 1.59 & 0.042 & 0.32 & 0.14 \\
\hline $620 / 060$ basalt & 51.7 & 82 & 39.5 & 18.0 & 6.1 & - & 62 & 0.78 & 200 & 2.5 & 0.80 & 0.51 & 1.65 & 0.045 & 0.33 & 0.18 \\
\hline \multicolumn{17}{|l|}{ Hakone } \\
\hline $\mathrm{K} 1$ andesite & 26.6 & 53 & 24.8 & 22.0 & 4.3 & - & 82 & 0.47 & 152 & 5.2 & 0.97 & 0.44 & 1.72 & 0.096 & 0.53 & 0.18 \\
\hline K7 andesite & 33.3 & 53 & 25.8 & 12.0 & 7.8 & - & 62 & 0.87 & 205 & 3.4 & 0.69 & 0.43 & 1.82 & 0.072 & 0.56 & 0.24 \\
\hline $\mathrm{K} 5$ andesite & 9.8 & 7 & 1.0 & $<1.3$ & 17.0 & 124 & 138 & 0.91 & 482 & 6.4 & 1.13 & 0.61 & 4.38 & 0.168 & 1.28 & 0.50 \\
\hline \multicolumn{17}{|l|}{ Calc-alkalic series } \\
\hline \multicolumn{17}{|l|}{ Fuji } \\
\hline $\mathrm{F} 2$ & 33.5 & 106 & 40.2 & 55 & 11.5 & 428 & 113 & 0.87 & 198 & 7.6 & 1.34 & 0.64 & 2.59 & 0.122 & 1.21 & 0.35 \\
\hline \multicolumn{17}{|l|}{ Omuro-yama } \\
\hline OM1 high- & 30.2 & 217 & 40.7 & 111 & 5.2 & - & 62 & 0.25 & 85 & 5.8 & 0.97 & 0.45 & 1.58 & 0.162 & 0.65 & 0.15 \\
\hline OM5 olivine andesite & 19.9 & 95 & 24.0 & 43 & 20.6 & - & 136 & 1.15 & 269 & 9.8 & 0.99 & 0.48 & 2.87 & 0.280 & 2.13 & 0.73 \\
\hline OM8 olivine andesite & 28.4 & 64 & 30.1 & 31 & - & 445 & 79 & 0.32 & 150 & 6.3 & 1.03 & 0.39 & 1.94 & 0.12 & 0.99 & 0.33 \\
\hline OM3 olivine andesite & 27.6 & 36 & 27.4 & 22 & 8.5 & 418 & - & 0.46 & 147 & 5.7 & 0.97 & 0.40 & 1.80 & 0.11 & 0.80 & 0.23 \\
\hline OM4 olivine andesite & 22.9 & 86 & 27.3 & 48 & 14.7 & 351 & 104 & 0.47 & 114 & 7.6 & 1.03 & 0.44 & 2.18 & 0.21 & 1.31 & 0.43 \\
\hline OM6 olivine andesite & 24.3 & 117 & 28.0 & 68 & 11.1 & 412 & 87 & 0.48 & 154 & 6.7 & 1.10 & 0.45 & 1.99 & 0.17 & 1.01 & 0.31 \\
\hline \multicolumn{17}{|l|}{ Asama } \\
\hline AS625 high-Al basalt & 27.7 & 219 & 35.4 & 82 & 4.4 & 350 & 59 & 0.19 & 84 & 3.9 & 0.71 & 0.35 & 1.32 & 0.088 & 0.51 & 0.08 \\
\hline AS310 high-Al basalt & 30.6 & 60 & 30.1 & 15.5 & 7.4 & 277 & 65 & 0.17 & 93 & 4.1 & 0.79 & 0.42 & 1.63 & 0.138 & 0.89 & 0.23 \\
\hline AS623 andesite & 22.3 & 183 & 29.2 & 62 & 12.3 & 339 & 69 & 0.46 & 136 & 4.8 & 0.74 & 0.34 & 1.76 & 0.110 & 1.05 & 0.35 \\
\hline AS264 dacite & 11.8 & 12 & 4.3 & 0 & 47.0 & 255 & 141 & 2.73 & 391 & 12.2 & 1.06 & 0.61 & 4.35 & 0.380 & 4.45 & 1.23 \\
\hline
\end{tabular}

cesses (unless very small degrees of melting are involved, i.e., $<5 \%$ ) and are representative of their mantle sources. On the Th versus La diagram, all the Japanese basalt types generally fall within a narrow range of $\mathrm{La} / \mathrm{Th}$ ratios $(\sim 4-8)$ which are lower than the chondritic value. In contrast, N-type MORB has much higher $\mathrm{La} / \mathrm{Th}$ ratios (15-25), and most E- and T-type MORB have $\mathrm{La} / \mathrm{Th}$ ratios $(\sim 8-15)$ intermediate between those of N-type MORB and chondritic values. The E-type MORB basalts from $45^{\circ} \mathrm{N}$ on the Mid-Atlantic Ridge are an exception to this in having lower $\mathrm{La} / \mathrm{Th}$ ratios, similar to those of the Oki-Dogo series. All the Site 446 basalts and unit 444-1 plot in the same area as E-type MORB in Figure 14, together with similar basalts from Iceland and the Azores.

The plot of $\mathrm{Ba}$ versus $\mathrm{La}$ also discriminates between the Leg 58 basalts and the Japanese lava series. More- over, it discriminates between the island-arc tholeiites and high-alumina-basalt series. The $\mathrm{Ba} / \mathrm{La}$ ratios of the MORB types are close to the bulk-Earth value $(\sim 10.5$; Ganapathy and Anders, 1974), but vary from about 4 in $\mathrm{N}$-type MORB up to 20 in some E-type MORB alkali basalts (e.g., Azores). The Leg 58 basalts fall within this range, the alkalic group from Site 446 having the highest $\mathrm{Ba} / \mathrm{La}$ ratios $(\sim 15)$. In contrast, almost all the islandarc magma types have $\mathrm{Ba} / \mathrm{La}$ ratios greater than 20 . The high-alumina-basalt and alkali-basalt series have $\mathrm{Ba} / \mathrm{La}$ ratios between 20 and 25 , whereas the tholeiitic series have $\mathrm{Ba} / \mathrm{La}$ ratios close to 80 . The data of Masuda et al. (1975) for the tholeiitic, high-alumina-basalt, and alkali-basalt series of Hokkaido and northern Honshu, and their associated calc-alkalic series, have been included in Figure 15 . These data are consistent with our results and show that the tholeiitic series consistently have higher 

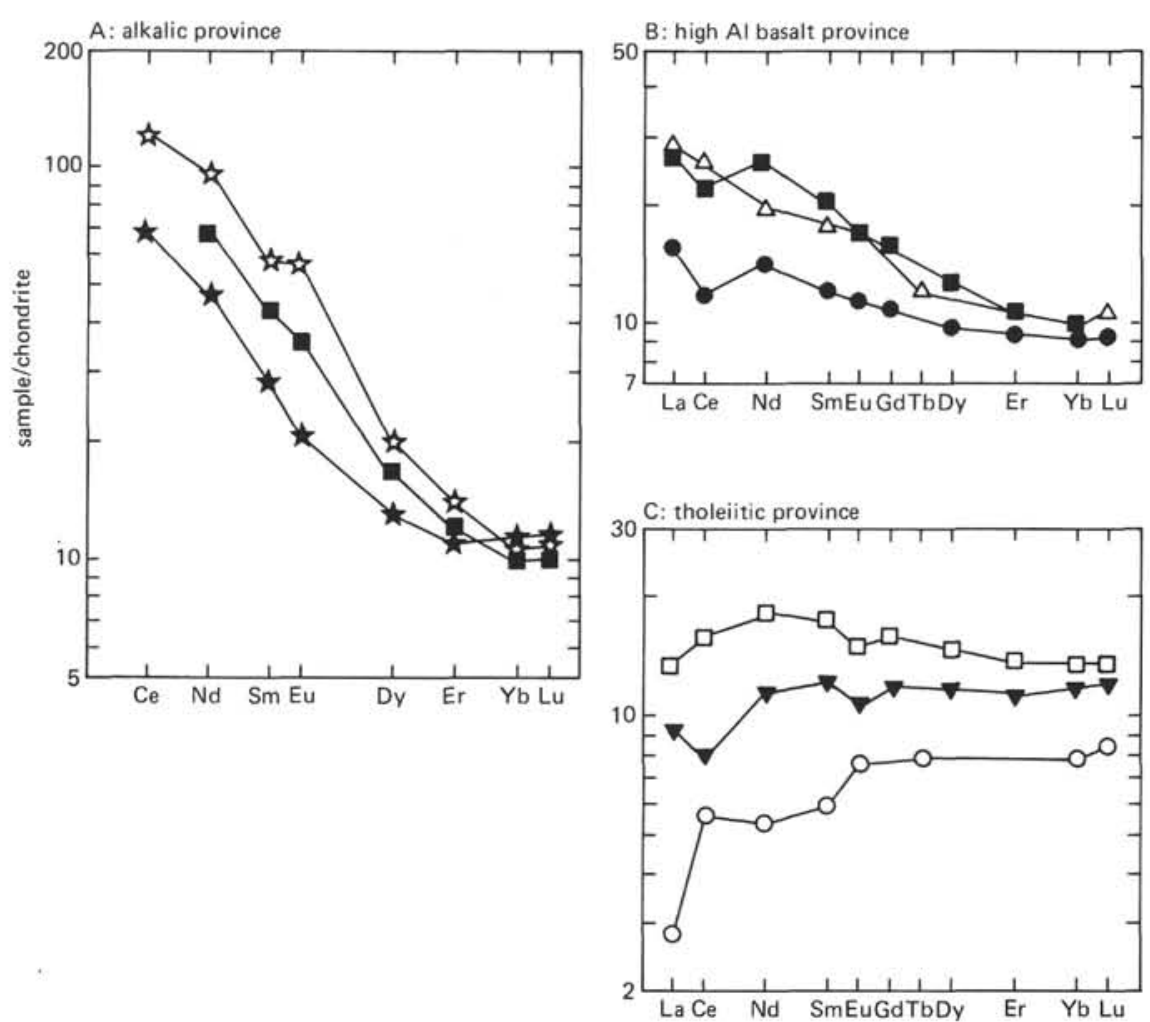

Figure 10. Chondrite-normalized REE diagrams for lavas from the basalt provinces of Japan. The data have been taken from the literature. For the alkalic province, all samples are from Oki-Dogo; the closed stars are trachybasalt (MU6072604); the closed squares are trachybasalt (MU60525); the open stars are mugearite (MU60520; Nagasawa, 1973). For the high-alumina-basalt province, the closed circles are for a basalt from Nii-Jima (Masuda, 1968); the open triangles are basalt (HK53010101) from Komuro-yama (Yajima et al., 1972); and the closed squares are for a basalt from Fuji (Masuda, 1968). For the tholeiitic province, the open circles are basalt (HK36092301-6) from Oshima (Yajima et al., 1972); closed inverted triangles are for a basalt from Oshima (Masuda, 1968); and open squares are for andesite 3 from the Hakone volcano (Fujimaki, 1975).

$\mathrm{Ba} / \mathrm{La}$ ratios than the other series. All the calc-alkalic lavas associated with the main magma types also have high $\mathrm{Ba} / \mathrm{La}$ ratios, which are usually higher than the alkalic and high-alumina-basalt series and lower than the tholeitic series.

Whereas $\mathrm{Ba}$, Th, etc. are enriched in the island-arc magma series relative to the MORB types, those moreHYG elements with small ionic radii and high charge (high-field-strength elements), e.g., $\mathrm{Ta}$ and $\mathrm{Nb}$, are strongly depleted in the island-arc tholeiites and highalumina basalts relative to MORB types. Although we have no Ta data for the Leg 58 basalts, we have included a $\mathrm{La}$ versus $\mathrm{Ta}$ diagram (Figure 16) for the Japanese samples and for the MORB types from the North Atlantic Ocean. The island-arc tholeiites, high-alumina basalts, and associated calc-alkalic lavas have $\mathrm{La} / \mathrm{Ta}$ ratios close to 50 , whereas $\mathrm{N}$-type MORB has $\mathrm{La} / \mathrm{Ta}$ close to 16 , and E- and T-type MORB have La/Ta close to 10 (Joron et al., 1978; Wood et al., 1979, in press). The Oki-Dogo alkalic series has La/Ta ratios close to 10, the same as E-type MORB. The higher Ba and Th contents of the Oki-Dogo series relative to E-type MORB are probably a consequence of crustal contamination, as discussed before. Excluding those elements, there is an overall similarity between the Oki-Dogo series and E-type MORB. Thus, they probably represent the products of the same petrogenetic processes acting on a similar range of mantle source compositions. Dupuy et al. (1977), in their survey of the geochemistry of the volcanic series associated with subduction zones, concluded that the alkalic and shoshonitic members were derived by processes and from sources similar to those of alkalic series from other tectonic environments. Johnson et al. (1978) have also stressed that the alkali basalts associated with the active-margin volcanic series of Papua, New Guinea, may not be directly related to 


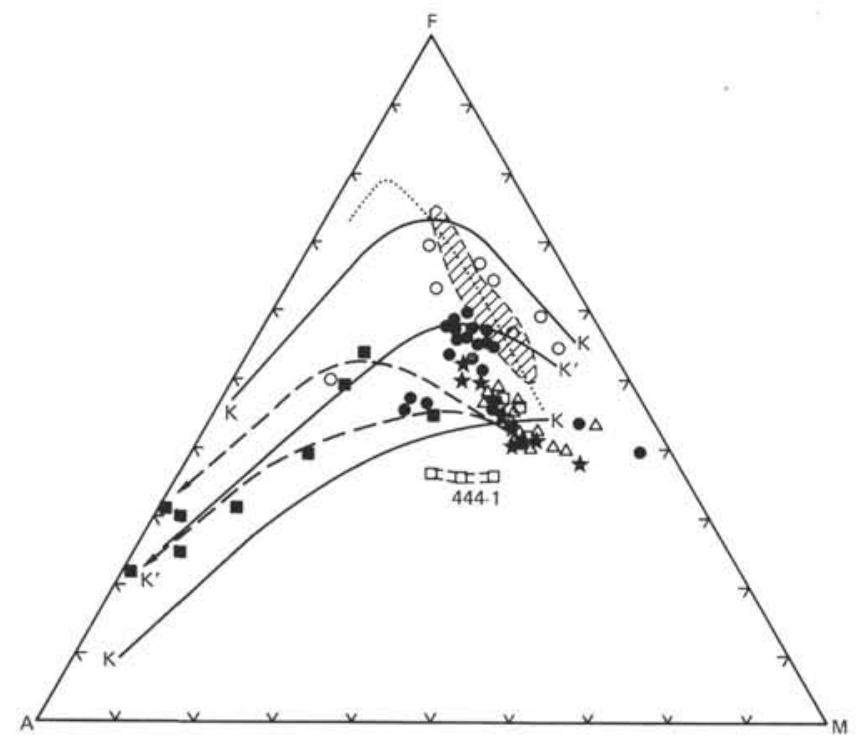

Figure 11. $\left(\mathrm{Na}_{2} \mathrm{O}+\mathrm{K}_{2} \mathrm{O}\right)-\mathrm{FeO}-\mathrm{MgO}(\mathrm{AFM})$ triangular diagram for Leg 58 basalts and selected Japanese lavas. The symbols for the Leg 58 samples are as in Figure 2. Open circles are lavas from the tholeiitic province of Japan (Table 5). Closed squares are lavas from the alkalic province of Japan (Table 4). Shaded area shows the range of basalts drilled in $63^{\circ} \mathrm{N}$ in the Atlantic Ocean (Wood et al., 1979a). The dotted line is the Skaergaard fractionation trend. The dashed lines are the high-and low-iron fractionation trends of the Oki-Dogo series (Uchimizu, 1966). The curved lines $K-K$ represent the general limits of Japanese lavas, the pigeonitic series plotting above line $K^{\prime}-K^{\prime}$, and the hypersthenic series plotting below it (Kuno, 1968).

the subduction zones. We also conclude that the composition of alkalic lava series is not directly dependent on their tectonic environment.

It is apparent from Figures 13 to 15 that it is variations among the more-HYG elements that are the most sensitive discriminators of subduction-zone volcanic series and MORB series. Comparison of REE patterns in both series (Figures 8 and 10) indicates that the REE are not very good discriminators; light-REE-enriched and -depleted types are found in both environments.

\section{PETROGENESIS}

Extensive petrological, experimental, trace-element, and isotope data on island-arc and continental-margin magma series accumulated during the last decade indicate that they are derived from an upper-mantle source. In consequence, it has been necessary to invoke a process causing the enrichment of the upper-mantle source in $\mathrm{K}, \mathrm{Ba}, \mathrm{Th}$, and radiogenic $\mathrm{Sr}$ and $\mathrm{Pb}$ relative to the mantle sources of the MORB types. Ringwood (1974) proposed the involvement of a liquid component derived by partial melting of quartz eclogite, whereas Best (1975) suggested that fluids derived from the dehydration of oceanic crust in the subduction zone permeate the lithosphere overriding the zone. In more-

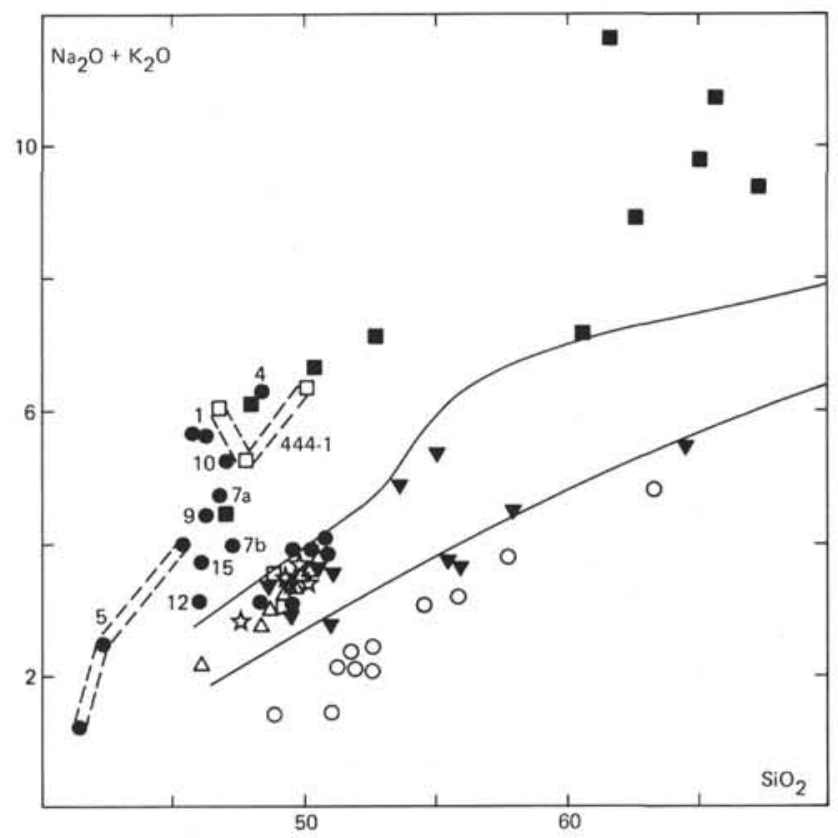

Figure 12. Alkalis versus silica diagram (wt. \%) for Leg 58 samples and selected Japanese lavas. Symbols and numbers for Leg 58 samples are as in Figure 2. Symbols for Japanese lavas are as those in Figure 11; the inverted, closed triangles represent the highalumina-basalt series (Table 6). The curved lines represent the general limits of the high-aluminabasalt series (Kuno, 1968).

recent trace-element and isotope studies, it is the latter model that has received the most support (Hawkesworth et al., 1978, 1979; Sun, in press; Saunders et al., 1979). The effect of a hydrous fluid/incipient melt on the surrounding mantle would be to lower the solidus and induce partial melting under conditions of high $P_{\mathrm{H}_{2} \mathrm{O}}$ and $f_{\mathrm{O}_{2}}$. The trace-element and isotope composition of the resulting magma would depend on several factors: 1) the respective compositions of the fluid and the mantle involved; 2) their relative proportions; 3 ) degree of partial melting; and 4) depth of melting, i.e., the presence or absence of garnet in the residue of partial melting. The composition of the fluid/incipient melt phase would also be dependent on factors 3 and 4 .

The depletion of the high-field-strength elements in island-arc tholeiite and calc-alkalic magmas (Saunders et al., 1979) indicates the presence of a titanium-bearing phase in the mantle source residue (e.g., ilmenite, sphene, rutile), because these are the only phases into which $\mathrm{Ta}$ and $\mathrm{Nb}$ are partitioned significantly more strongly than the other more-HYG elements. Stability of such phases would be enhanced by the high $P_{\mathrm{H}_{2} \mathrm{O}}$ and $f_{\mathrm{O}_{2}}$ in the mantle source. A consequence of this would be to generate a refractory mantle residue or subducted lithosphere enriched in the high-field-strength elements relative to the other more-HYG elements. Thus, assuming that the subducted lithosphere had the $\mathrm{La} / \mathrm{Ta}$ ratio of N-type MORB (its main constituent), which is close to a bulk-Earth value, the dehydrated residue would 


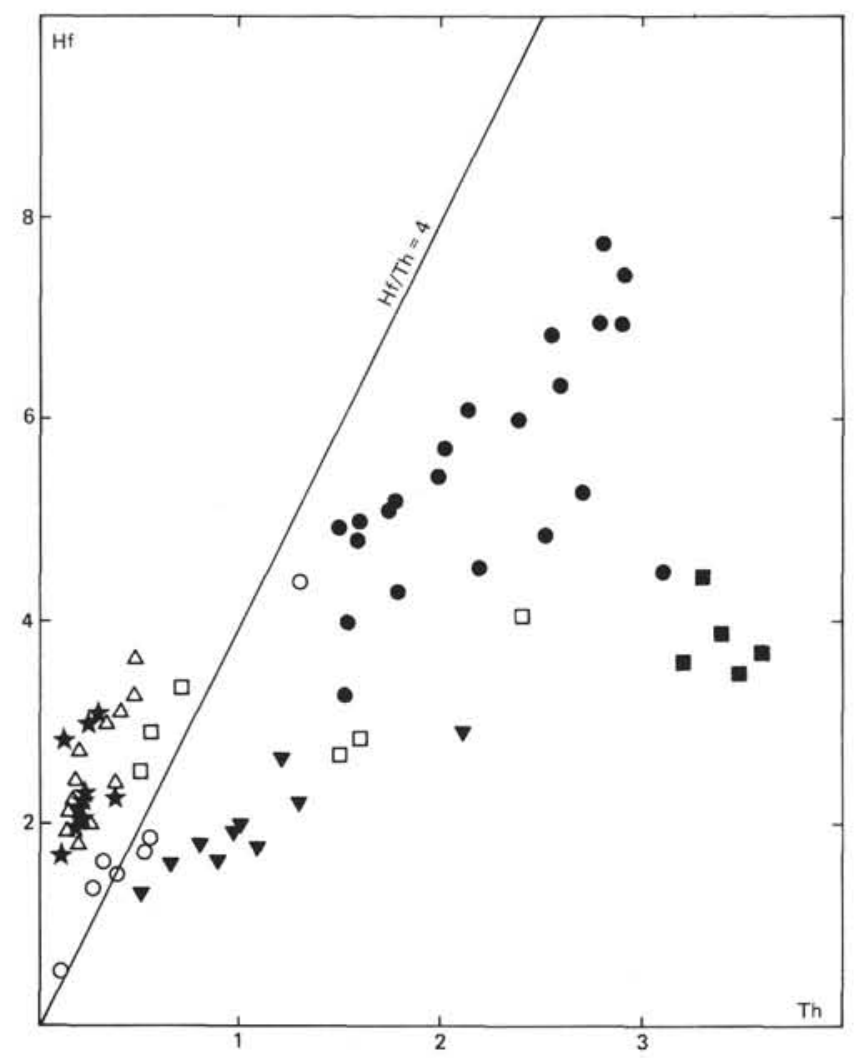

Figure 13. Hf versus Th for Leg 58 basalts and Japanese lava series. Symbols are as in Figure 11. Concentrations are in ppm.

have a lower $\mathrm{La} / \mathrm{Ta}$ ratio. Wood et al. (in press) have suggested that this fractionation of the high-fieldstrength ions from the other more-HYG elements at active plate margins may be the cause of the low $\mathrm{La} / \mathrm{Ta}$ ratios in T- and E-type MORB, i.e., a component of the mantle sources of these MORB has been previously involved in magma genesis at active plate margins. The occurrence of E-type MORB in a back-arc basin, and the low $\mathrm{La} / \mathrm{Ta}$ ratios of the Oki-Dogo alkalic series are consistent with this hypothesis.

Although it is possible to explain the enrichment of the more-HYG elements in alkali basalts by small degrees of partial melting $(<5 \%)$ of a mantle source with relative abundances of the HYG elements similar to the bulk Earth (Gast, 1968; Kay and Gast, 1973), experimental studies have suggested that slightly higher degrees of melting are involved (Green and Ringwood, 1967). Frey et al. (1978) reconciled the trace-element and experimental evidence by proposing a mantle source which was enriched in the more-HYG elements. The most reasonable way to enrich a portion of the mantle is to vein (metasomatize) it with a fluid or melt. The occurrence of mantle-derived, veined peridotite nodules in alkalic magmas (Frey and Green, 1974) testifies that enrichment of the mantle and re-enrichment of depleted mantle does take place. Hanson (1977), Tarney et al. (1979b), and Wood et al. (in press) have shown that a variably veined sub-oceanic mantle can explain many of

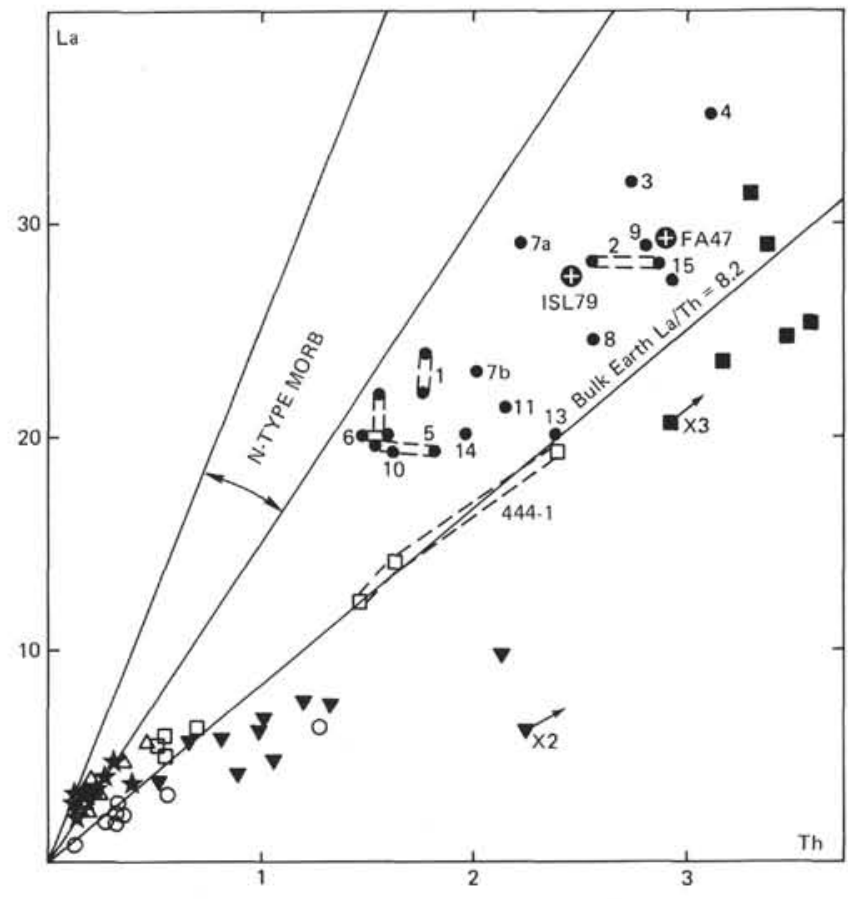

Figure 14. La versus Th for Leg 58 basalts and Japanese lava series. Symbols are as in Figure 11. Iceland basalt (ISL79) and Azores basalt (FA47; Table 1) are also shown. Symbols plotted with arrows indicate that the measured concentrations in these samples have been divided by the number given in order to plot on the diagram. Concentrations are in ppm.

the trace-element and isotope variations among the MORB types. Veining parts of the upper mantle with a fluid or incipient melt derived from dehydrated subducted lithosphere once it has been transformed to quartz eclogite could explain the low $\mathrm{La} / \mathrm{Ta}$ ratio and enrichment of the more-HYG elements in E- and T-type MORB sources.

Gast (1968) demonstrated that the mantle source of $\mathrm{N}$-type MORB is depleted in the more-HYG elements relative to the bulk Earth. Subsequently, several studies of $\mathrm{Sr}$ and Nd isotopes (e.g., O'Nions et al., 1977) have indicated that the $\mathrm{N}$-type MORB mantle source has been depleted in these elements for a substantial period of Earth history. Moreover, the isotope evidence suggests that the mantle sources of E- and T-type MORB have also had a time-integrated depletion of these elements, and the enrichment of these sources must have occurred relatively recently (within Phanerozoic time) in order to preserve lower ${ }^{87} \mathrm{Sr} /{ }^{86} \mathrm{Sr}$ and higher ${ }^{143} \mathrm{Nd} /{ }^{144} \mathrm{Nd}$ ratios than the bulk Earth in most E-type MORB. Thus, in this model the mantle sources of E- and T-type MORB have had a complex history, involving depletion and enrichment events.

Although the mantle source of N-type MORB is depleted in the more-HYG elements, consideration of the abundance and ratios among the HYG elements indicates that the depletion event could have involved only 


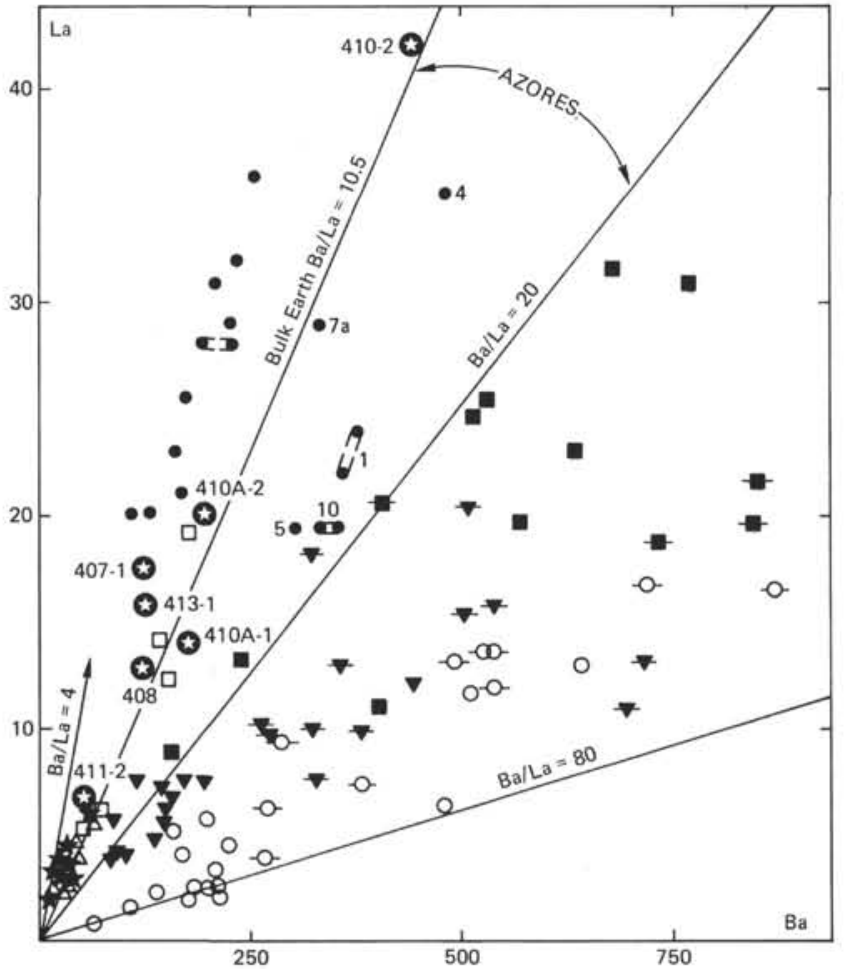

Figure 15. La versus Ba for Leg 58 basalts and Japanese lava series. Symbols are as in Figure 11. In addition to analyses of Japanese lavas given in Table 7, data for lava series from Hokkaido, Japan (Masuda et al., 1975) have also been plotted, using the same symbols. Horizontal bars through some symbols of the Hokkaido lavas indicate that these are calc-alkalic rocks erupted in the respective basalt provinces. Stars in circles represent selected basalts from the North Atlantic Ocean floor (Wood et al., 1979a). Concentrations are in ppm.

the extraction of a melt or fluid phase amounting to less than 1 per cent of the system if it was derived from a pristine mantle of bulk-Earth composition by a twostage process (Hanson, 1977). The depletion event(s) could have involved the extraction of larger proportions of melt if one assumes a continuous remixing model in which basalt is extracted from the upper mantle throughout Earth history, and that a significant proportion is recycled and remixed with the depleted mantle by the convective overturn of the oceanic crust and upper mantle (O'Nions et al., in press). The striking homogeneity of N-type MORB from all the oceans would require the remixing to be very efficient on all scales for the concept of the latter process to be viable. Certainly the evidence we have from the upper mantle (sub-oceanic and subcontinental) from nodules suggests that this is not the case: mantle nodules show a wide range of $\mathrm{Fe} / \mathrm{Mg}$ ratios and HYG-element compositions; the existence of enriched sources with a wide range of isotope and traceelement compositions indicates that remixing processes are more likely to generate heterogeneity than homo-

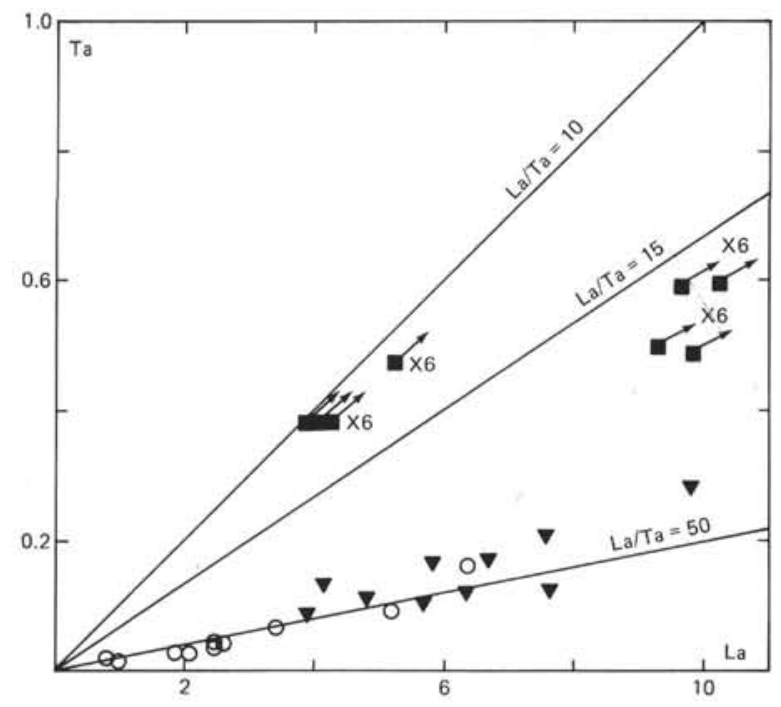

Figure 16. Ta versus La for Japanese lava series. Symbols are as in Figure 11. Arrows indicate that the measured concentrations of Ta and La in the alkalic series have been divided by 6 in order to plot on this diagram. The lines of $\mathrm{La} / \mathrm{Ta}$ ratios 10 and 15 represent the general limits of MORB types. Concentrations are in ppm.

geneity in the mantle source of N-type MORB. We believe, therefore, that the depletion of much of the mantle by incipient-melting or fluid-transfer processes involved in the early degassing of the Earth are more likely to result in a homogeneous (fertile) residual mantle than remixing processes. In this type of model, $\mathrm{N}$-type MORB mantle source has not suffered extensive extraction of basaltic melt and has therefore had a less complex history than E- and T-type MORB mantle sources.

The mantle residues left by the extraction of basalt will have much lower $\mathrm{Fe} / \mathrm{Mg}$ ratios and $\mathrm{HYG}$-element contents than pristine mantle. These residues will be less dense and therefore maintain a position near the top of the mantle. This type of refractory material will have a statistically higher chance of being veined by fluids or melts from below than deeper material. Many of the veined nodules which have been studied contain such a refractory component. In a veined mantle, it is the composition of the vein which controls the HYG-element composition of the bulk material, but it is the composition of the refractory component which controls the $\mathrm{Fe} / \mathrm{Mg}$ ratio and major-element composition. This may explain why there are low- and high-Fe varieties of E-type MORB (e.g., the basalts of unit 444-1 and 446, respectively), the low-Fe variety coming from the morerefractory source. Melts derived from the most refractory veined sources would have HYG-element abundances most closely resembling those of the veins, which may explain why the low-Fe varieties of E-type MORB have higher ratios of more-HYG to less-HYG elements (e.g., La/Sm and Th/Hf; Langmuir and Hanson, 1979; Wood et al., in press). 
One consequence of the veined-mantle model is that the sources of E- and T-type MORB are situated above the source of N-type MORB; this is the reverse of the many variations of the mantle-plume model. If $\mathrm{N}$-type MORB is generated by partial melting induced by decompression in the upwelling limb of a convection cell, it is possible that the melt will be formed at a shallower depth than E-type MORB, despite the fact that the source has originated from a greater depth in the mantle.

To explain the enrichment of the high-field-strength elements in E-type MORB by the veined-mantle model, it seems necessary to invoke the involvement of subduction-zone processes to cause the initial fractionation of these elements from the other HYG elements. Also, the enrichment of E-type MORB in radiogenic $\mathrm{Pb}$ and $\mathrm{Sr}$ isotopes and depletion in radiogenic $\mathrm{Nd}$ isotopes relative to $\mathrm{N}$-type MORB could be explained by incorporation (remixing) of a crustal component (DePaolo and Wasserburg, 1979), which would occur in subduction zones. It is possible that E-type MORB mantle sources are generated by veining mantle material with melts derived from the deeper parts of the Benioff zones, i.e., in a sub-continental or sub-continentalmargin environment. Perhaps this is the reason for the abundance of E-type MORB in the Atlantic Ocean, where much of the underlying mantle was sub-continental for at least the past $300 \mathrm{~m} . \mathrm{y}$. The eruption of E-type MORB in the marginal basins of the west Pacific Ocean is consistent with this interpretation.

\section{SUMMARY AND CONCLUSIONS}

The Leg 58 basalts are predominantly tholeiitic; alkalic types occur at Sites 444 and 446 . Many of the basalts from the Shikoku Basin are aphyric and have high Mg-numbers $(-7)$. However, the aphyric basalts from the Daito Basin have low Mg-numbers $(<0.55)$, suggesting that they have undergone significant crystal fractionation prior to eruption. All the Leg 58 basalts are compositionally related to the basalt types erupted in the major ocean basins (i.e., at mid-ocean ridges and ocean islands). The trace-element variations measured in the tholeiitic types are similar to those observed from the Reykjanes Ridge and Iceland; variation is from normal or N-type MORB strongly depleted in the moreHYG elements relative to the less-HYG elements (most units from Sites 442 and 443), through transitional or T-type MORB units (443-3 and 444-2), to enriched or E-type MORB less depleted and in some cases enriched in the more-HYG elements relative to the less-HYG elements (quartz-normative ferrobasalts at Site 446).

The Leg 58 tholeiitic basalts can be distinguished readily from the tholeiitic and high-alumina-basalt series of the Japanese island-arc systems by their majorand trace-element chemistry. The affinities of the Leg 58 tholeiitic basalts with ocean-floor basalts, rather than with those erupted in island arcs, are most clearly revealed on plots of $\mathrm{Ba}$ versus $\mathrm{La}$ and $\mathrm{Th}$ versus $\mathrm{La}$ (i.e., ocean-floor basalts have much lower ratios of $\mathrm{Ba} / \mathrm{La}$ and $\mathrm{Th} / \mathrm{La}$ than island-arc tholeiites). REE patterns do not discriminate between ocean-floor and island-arc tholeiites.
The alkalic basalts show a range of major- and traceelement compositions. The alkali basalt at Site 444 has low $\mathrm{FeO}$ and $\mathrm{TiO}_{2}$, but high alkali contents, whereas the alkali basalts at Site 446 have higher $\mathrm{FeO}$ and $\mathrm{TiO}_{2}$, but similar alkali contents. The alkali basalt at Site 444 is similar to some basalts recovered at $45^{\circ} \mathrm{N}$ on the MidAtlantic Ridge, and the alkali basalts from Site 446 are similar to some of the more-evolved (low $\mathrm{MgO}$ ) lavas erupted in the Azores. These similarities between alkali basalts from the north Philippine Sea floor and those from the Atlantic extend to ratios between more-HYG elements (e.g., $\mathrm{Th} / \mathrm{La}$ and $\mathrm{Ba} / \mathrm{La}$ ), indicating that they have been derived from similar mantle source compositions.

The compositions of the alkalic basalts from Japan fall within the range of major- and trace-element compositions shown by Leg 58 and oceanic alkali basalts. The alkalic series from Oki-Dogo, Japan, does have slightly higher $\mathrm{Ba} / \mathrm{La}$ and $\mathrm{Th} / \mathrm{La}$ ratios than the Leg 58 basalts, but this could reflect contamination by continental crust and is probably not indicative of different mantle source compositions. The Japanese alkalic series has $\mathrm{La} / \mathrm{Ta}$ ratios similar to those of E-type MORB, which also suggests that, unlike the mantle sources of tholeiitic basalts, the composition of the mantle sources of alkali basalts is not directly dependent upon tectonic environment.

The enrichment of island-arc magmas in $\mathrm{K}, \mathrm{Ba}$, and Th relative to the other more-HYG elements supports the involvement of a component derived from the dehydration or incipient melting of subducted lithosphere in their mantle sources. The very low abundances of Ta and $\mathrm{Nb}$ in island-arc magmas indicate that these elements have been retained in the mantle residue or subducted lithosphere during their genesis. $\mathrm{Ta}$ and $\mathrm{Nb}$ are strongly partitioned in Ti-oxide phases which will be more stable under the higher $P_{\mathrm{H}_{2} \mathrm{O}}$ and $f_{\mathrm{O}_{2}}$ conditions of this environment. The residue will therefore become enriched in Ta relative to the other more-HYG elements. E-type MORB and alkali basalts have lower $\mathrm{La} / \mathrm{Ta}$ ratios than the bulk Earth or N-type MORB. The fractionation of $\mathrm{Ta}$ and $\mathrm{Nb}$ from the other more-HYG elements in island-arc magma genesis may be indirectly responsible for the low La/Ta ratios in E-type MORB; a component of the mantle sources of E-type MORB and alkali basalts could be derived from residual material involved in island-arc magma genesis.

We propose a model in which E-type MORB and alkali basalts are derived from complex, veined mantle sources consisting of two or more components which have undergone different evolutionary histories, including both enrichment (addition of fluids and/or melts by veining) and depletion (extraction of fluids and/or melts). This model can explain the element and radiogenic-isotope variation displayed by E-type MORB and alkali basalts more satisfactorily than mantle-plume models.

\section{ACKNOWLEDGMENTS}

This study was supported by the Natural Environment Research Council (U. K.) and the Centre National de la 
Recherche Scientifique (France). D. A. W. gratefully acknowledges a NERC post-doctoral fellowship.

\section{REFERENCES}

Aoki, F.-I., and Oji, Y., 1966. Calc-alkaline volcanic rock series derived from alkali-olivine basalt magma. J. Geophys. Res., 71, 6127-6135.

Arculus, R. J., and Johnson, R. W., 1978. Criticism of generalised models for the magmatic evolution of arc-trench systems. Earth Planet. Sci. Letters, 39, 118-126.

Best, M. G., 1975. Migration of hydrous fluids in the upper mantle and potassium variation in calc-alkalic rocks. Geology, 3, 429-432.

Bougault, H., Cambon, P., Corre, O., Treuil, M., and Joron, J.-L., 1979. Evidence for variability of magmatic processes and upper mantle heterogeneity in the axial region of the Mid-Atlantic Ridge near $22^{\circ}$ and $36^{\circ} \mathrm{N}$. Tectonophysics, 5(1-2), 11-34.

Chayla, B., Jafrezic, H., and Joron, J.-L., 1973. Analyse par activation dans les mentions épithermiques. Application à la détermination d'éléments en trace dans les roches. Comptes Rendus Acad. Sci. Paris, 277, 273-275.

DePaolo, D. J., and Wasserburg, G. J., 1979. Petrogenetic mixing models and $\mathrm{Nd}-\mathrm{Sr}$ isotopic patterns. Geochim. Cosmochim. Acta, 43, 615-627.

Dickinson, W. R., and Hatherton, T., 1967. Andesitic volcanism and seismicity around the Pacific. Science, 157, 801-803.

Dietrich, V., Emmermann, R., Oberhansli, R., and Puchelt, H., 1978. Geochemistry of basaltic and gabbroic rocks from the West Mariana Basin and the Mariana Trench. Earth Planet. Sci. Letters, 39, 127-144.

Dupuy, C., Dostal, J., and Vernières, J., 1977. Genesis of volcanic rocks related to subduction zones, geochemical point of view. Bull. Soc. Geol. France, 19, 1233-1243.

Engel, A. E., Engel, C. G. and Havens, R. G., 1963. Chemical characteristics of oceanic basalts and the upper mantle. Geol. Soc. Am. Bull., 76, 719-734.

Frey, F. A., Bryan, W. B., and Thompson, G., 1974. Atlantic Ocean floor: geochemistry and petrology of basalts from Legs 2 and 3 of the DSDP. J. Geophys. Res., 79, 5507-5527.

Frey, F. A. and Green, D. H., 1974. The mineralogy, geochemistry and origin of lherzolite inclusions in Victorian basanites. Geochim Cosmochim Acta, 38, 1023-1059.

Frey, F. A., Green, D. H., and Roy, S. D., 1978. Integrated models of basalt petrogenesis. J. Petrol., 19, 463-513.

Fujimaki, H., 1975. Rare earth elements in volcanic rocks from Hakone volcano and northern Izu Peninsula, Japan. J. Faculty Sci., Univ. Tokyo, Sect. 2, 19, 81-93.

Ganapthy, R., and Anders, E., 1974. Bulk composition of the Moon and Earth estimated from meteorites. Proc. Lunar Sci. Conf., 5, 1181-1206.

Gast, P. W., 1968. Trace element fractionation and the origin of tholeiitic and alkaline magma types. Geochim. Cosmochim. Acta, 32, 1057-1086.

Gill, J. B., 1976. Composition and age of Lau Basin and Ridge volcanic rocks: implications for evolution of an interarc basin and remnant arc. Geol. Soc. Am. Bull., 87, 1384-1395.

Green, D. H., and Ringwood, A. E., 1967. The genesis of basalt magmas. Contr. Mineral. Petrol., 15, 103-190.

Hanson, G. N., 1977. Evolution of the suboceanic mantle. J. Geol. Soc., 134, 235-253.

Hart, S. R., 1971. K, Rb, Cs, Sr and Ba contents and Sr isotope ratios of ocean floor basalts. Philos. Trans. Roy. Soc., Ser. A, 268, 573-588.

Hart, S. R., Glassley, W. E., and Karig, D. E., 1972. Basalts and sea floor spreading behind the Mariana Island arc. Earth Planet. Sci. Letters, 15, 12-18.
Hawkesworth, C. J., O'Nions, R. K., Pankhurst, R. J., Hamilton, P. J., and Evensen, N. M., 1978. A geochemical study of island arc and back arc tholeiites from the Scotia Sea. Earth Planet. Sci. Letters, 36, 253-262.

Hawkesworth, C. J., Norry, M. J., Roddick, J. C., Baker, P. E., Francis, P. W., and Thorpe, R. S., 1979. ${ }^{143} \mathrm{Nd} /$ ${ }^{144} \mathrm{Nd},{ }^{87} \mathrm{Sr} /{ }^{86} \mathrm{Sr}$ and incompatible trace element variations in calc-alkaline andesites and plateau lavas from South America. Earth Planet. Sci. Letters, 42, 45-57.

Hawkins, J. W., Jr., 1976. Petrology and geochemistry of basaltic rocks from the Lau Basin. Earth Planet. Sci. Letters, 28, 283-297.

Isshiki, N., 1963. Petrology of Hachijo-jima volcano group, Seven Izu Islands, Japan. J. Faculty Sci., Univ. Tokyo, Sec. 2, 15, 91-134.

Jakes, P., and Gill, J., 1970. Rare earth elements and the island arc tholeiitic series. Earth Planet. Sci. Letters, 9, 17-18.

Jakes, P., and White, A. J. R., 1972. Major and trace element abundances in volcanic rocks of orogenic areas. Geol. Soc. Am. Bull., 83, 29-40.

Johnson, R. W., McKenzie, D. E., and Smith, I. E. M., 1978. Volcanic rock associations at convergent plate boundaries: reappraisal of the concept using case histories from Papua, New Guinea. Geol. Soc. Am. Bull., 89, 96-106.

Joron, J.-L., Bougault, H., Wood, D. A., and Treuil, M., 1978. Application de la géochimie des éléments en trace à l'étude des propriétés et des processus de genèse de la croûte océanique et du manteau supérieur. Bull. Soc. Geol. France, 20, 521-531.

Karig, D. E., 1975. Basalt genesis in the Philippine Sea. In Karig, D. E., Ingle, J. C., Jr., et al., Init. Repts. DSDP, 31: Washington (U. S. Govt. Printing Office), pp. 857-879.

Katsui, Y., 1961. Petrochemistry of the Quaternary volcanic rocks of Hokkaido, Japan. Journal Faculty Sci., Hokkaido Univ., ser. 4, 11, 1-58.

Katsumata, M., and Sykes, L. R., 1969. Seismicity and tectonics of the western Pacific: Izu-Mariana-Caroline and Ryuku-Taiwan region. J. Geophys. Res., 74, 5923-5948.

Kay, R. W., and Gast, P. W., 1973. The rare earth element content and origin of alkali-rich basalts. J. Geol., 81, 653-682.

Kobayashi, K., and Isezaki, N., 1976. Magnetic anomalies in the Sea of Japan and the Shikoku Basin. Geophys. Monogr., 19, 235-253.

Kuno, H., 1950. Petrology of Hakone volcano and adjacent areas, Japan. Geol. Soc. Am. Bull., 61, 957-1020.

1954. Geology and petrology of Omuro-yama volcano group, North Izu, J. Faculty Sci., Univ. Tokyo, sec. $2,19,241-267$.

1959. Origin of Cenozoic petrographic provinces

of Japan and surrounding areas. Bull. Volcanol., 20, 37-76.

1960. High alumina basalt. J. Petrol., 1, 121-145.

1965. Fractionation trends of basalt magmas in lava flows. J. Petrol., 6, 302-321.

1966. Lateral variation of basalt magma type across continental margins and island arcs. Bull. Volcanol., 29, 195-222.

1968. Differentiation of basalt magmas. In, Hess, H. H., and Poldervaart, A. (Eds.), Basalts (Vol. 2): New York (Wiley), pp. 623-688.

Kurasawa, H., 1968. Isotopic composition of lead and concentrations of uranium, thorium and lead in volcanic rocks from Dogo of the Oki Islands. Geochem. J., 2, 11-28. 
Langmuir, C. H., and Hanson, G. N., in press. Do the compositions of basalts reflect major element heterogeneity in the mantle? Philos. Trans. Roy. Soc., Ser. A.

Masuda, A., 1968. Geochemistry of lanthanides in basalts of central Japan. Earth Planet. Sci. Letters, 4, 284-292.

Masuda, Y., Nishimura, S., Ikeda, T., and Katsui, Y., 1975. Rare earth and trace elements in the Quaternary volcanic rocks of Hokkaido, Japan. Chem. Geol., 15, 251-271.

Murauchi, S., Den, N., Asano, S., Hotta, H., Yoshii, T., Asanuma, T., Hagiwara, K., Ichikawa, K., Sato, T., Ludwig, W. J., Ewing, J., Edgar, N. T., and Houtz, R. E., 1968. Crustal Structure of the Philippine Sea. J. Geophys. Res., 73, 3134-3171.

Nagasawa, H., 1973. Rare earth distribution in alkali rocks from Oki-Dogo Island, Japan. Contr. Mineral. Petrol., 39, 301-308.

Nakamura, K., 1974. Determination of REE, Ba, Fe, Mg, Na and $\mathrm{K}$ in carbonaceous and ordinary chondrites. Geochim. Cosmochim. Acta, 38, 757-775.

O'Hara, M. J., 1975. Is there an Icelandic mantle plume? Nature, 253, 708-710.

O'Nions, R. K., Evensen, N. M., and Hamilton, P. J., in press. Differentiation and evolution of the mantle. Philos. Trans. Roy. Soc. Ser. A.

O'Nions, R. K., Pankhurst, R. J., Fridleifsson, I. B., and Jakobsson, S. P., 1973. Sr-isotopes and rare earth elements in basalts from Heimaey and Surtsey volcanic eruptions. Nature, 243, 213-214.

O'Nions, R. K., Pankhurst, R. J., and Gronvold, K., 1976. Nature and development of basalt magma sources beneath Iceland and the Reykjanes Ridge. J. Petrol., 17, 3-30.

O'Nions, R. K., Hamilton, P. J., and Evensen, N. M., 1977. Variations in ${ }^{143} \mathrm{Nd} /{ }^{144} \mathrm{Nd}$ and ${ }^{87} \mathrm{Sr} /{ }^{86} \mathrm{Sr}$ ratios in oceanic basalts. Earth Planet. Sci. Letters, 34, 13-22.

Rhodes, J. M., Blanchard, D. P., Dungan, M. A., Rodgers, K. V., and Brannon, J. C., 1978. Chemistry of Leg 45 basalts. In Melson, W. G., Rabinowitz, P. D., et al., Init. Repts. DSDP, 45: Washington (U. S. Govt. Printing Office), pp. 447-459.

Ringwood, A. E., 1974. The petrological evolution of island arc systems. J. Geol. Soc. 130, 183-204.

Saunders, A. D., and Tarney, J., 1979. The geochemistry of basalts from a back-arc spreading centre in the East Scotia Sea. Geochim. Cosmochim. Acta 43, 555-572.

Saunders, A. D., Tarney, J., and Weaver, S. D., in press. Transverse geochemical variations across the Antarctic Peninsula: implications for the genesis of calc-alkaline magmas. Earth Planet. Sci. Letters.

Sun, S.-S., in press. Lead isotope study of young volcanic rocks from mid-ocean ridges, ocean islands and island arcs. Philos. Trans. Roy. Soc., Ser. A.

Sun, S.-S., Nesbitt, R. W., Sharaskin, A. Ya. in press. Chemical characteristics of mid-ocean ridge basalts. Earth Planet. Sci. Letters.

Tarney, J., Saunders, A. D., and Weaver, S. D., 1977. Geochemistry of volcanic rocks from the island arcs and marginal basins of the Scotia Arc region. In Talwani, M., and Pitman, W. C. (Eds.), Island Arcs, Deep Sea Trenches and Back-Arc Basins. Maurice Ewing Series, Vol. 1: Washington (American Geophysical Union), pp. 367-377.

Tarney, J., Saunders, A. D., Weaver, S. D., Donnellan, N. C. B. and Hendry, G. L., 1979a. Minor element geochemistry of basalts from leg 49, North Atlantic Ocean. In, Luyendyk, B. P., Cann, J. R., et al., Init. Repts. DSDP, 49: Washington (U. S. Government Printing Office), pp. 657-691.

Tarney, J., Wood, D. A., Saunders, A. D., Varet, J., and Cann, J. R., 1979b. Nature of mantle heterogeneity in the North Atlantic: evidence from Leg 49. In Talwani, M. (Ed.) Implications of Deep Drilling Results in the Atlantic Ocean. Maurice Ewing Series, Vol. 2: Washington (American Geophysical Union), pp. 285-301.

Taylor, S. R., Kaye, M., White, A. J. R., Duncan, A. R. and Ewart, A. 1969. Genetic significance of $\mathrm{Co}, \mathrm{Cr}, \mathrm{Ni}, \mathrm{Sc}$, and V content of andesites, Geochim. Cosmochim. Acta, 33, 275-286.

Tilley, C. E., 1950. Some aspects of magmatic evolution. Quart. J. Geol. Soc. London, 106, 37-61.

Tsuya, H., 1937. On the volcanism of the Huzi volcanic zone, with special reference to the geology and petrology of Idu and Southern Islands. Bull. Earthquake Res. Inst., Tokyo, $15,215-357$.

Uchimizu, M., 1966. Geology and petrology of alkali rocks from Dogo, Oki Islands. J. Faculty Sci., Univ. Tokyo, Sec. $2,16,85-159$.

Watts, A. B., and Weissel, J. K., 1975. Tectonic history of the Shikoku marginal basin. Earth Planet. Sci. Letters, 25, 239-250.

Weaver, S. D., Saunders, A. D., Pankhurst, R. J., and Tarney, J., 1979. A geochemical study of magmatism associated with the initial stages of back-arc spreading: the Quaternary volcanics of Bransfield Strait, from South Shetland Islands. Contr. Mineral. Petrol., 68, 151-169.

Wood, D. A., Gibson, I. L. and Thompson, R. N., 1976. Elemental mobility during zeolite facies metamorphism of the Tertiary basalts of Eastern Iceland. Contr. Mineral. Petrol., 55, 241-254.

Wood, D. A., Tarney, J., Varet, J., Saunders, A. D., Bougault, H., Joron, J.-L., Treuil, M., and Cann, J. R., 1979a. Geochemistry of basalts drilled in the North Atlantic by IPOD Leg 49: implications for mantle heterogeneity. Earth Planet. Sci. Letters, 42, 77-97.

Wood, D. A., Joron, J.-L., Treuil, M., Norry, M., and Tarney, J., in press. Elemental and $\mathrm{Sr}$ isotope variation in basic lavas from Iceland and the surrounding ocean floor: the nature of mantle source inhomogeneities. Contr. Mineral. Petrol.

Yajima, T., Higuchi, H., and Nagasawa, H., 1972. Variation of rare earth concentrations in pigeonitic and hypersthenic rock series from Izu-Hakone Region, Japan. Contr. Mineral. Petrol., 35, 235-244.

Yagi, K., Kawano, Y., and Aoki, K., 1963. Types of Quaternary volcanic activity in northeastern Japan. Bull. Volcanol., 26, 223-235. 